$12 / 3 / 2-9505(0)$

\title{
A Survey of the Wetlands and Floodplains of the Borrow Area and Wetland/Shorebird Complex for the Remedial Action at the Chemical Plant Area of the Weldon Spring Site
}

Environmental Assessment Division Argonne National Laboratory

Operated by The University of Chicago, under Contract W-31-109-Eng-38, for the United States Department of Energy DISTRIBUTION OF THIS DOCUMENT IS UNLIMITED 


\section{Argonne National Laboratory}

Argonne National Laboratory, with facilities in the states of Illinois and Idaho, is owned by the United States Government, and operated by the University

- $\therefore$ of Chicago under the provisions of a contract with the Department of Energy.

This fechnical memo is a product of Argonne's Environmental AssessmentDivision (EAD). For information on the division's scientific and engineering activities, contact:

Director, Environmental Assessmeńt Division

Argonne National Laboratory

Argonne, Illinois 60439-4815

Telephone (708) 252-3107

Presented in this technical memo are preliminary results of ongoing work or work that is more limited in scope and depth than that described in formal reports issued by the EAD.

\section{Publishing Support Services.}

Publishing súpport services provided by Árgonne's Informátion and Publishing Division.

\section{Disclaimeri $:$.}

This report was prepared as an account of work sponsored by an agency of the United States Government. 'Neither the United States Government nor any agency thereof, nor any of their employees, makes any warrantý, express or implied, or assumes any legal liability or responsibility for the accuracy, completeness, or usefulness of any information, apparatus, product, or process disclosed, or represents that its use would not infringe privately owned rights. Reference herein to any specific commercial product, process, or service by trade name, trademark, manufacturer, or otherwise, does not necessarily constitute or imply its endorsement, recommendation, or favoring by the United States Government or any agency thereof. The views and opinions of authors expressed herein do not necessarily state or reflect those of the United States Government or any agency thereof.

Reproduced directly from the best available copy.

Available to DOE and DOE contractors from the Office of Scientific and Technical Information, P.O. Box 62, , Oak Ridge, TN 37831; prices availlable from (615) 576-8401.

Available to the public from the National Technical Information Service, U.S. Department of Commerce, . 5285 Port Royal Road, Springfield, VA 22161. 


\section{DISCLAIMER}

Portions of this document may be illegible in electronic image products. Images are produced from the best available original document. 


\section{A Survey of the Wetlands and Floodplains of the Borrow Area and Wetland/Shorebird Complex for the Remedial Action at the Chemical Plant Area of the Weldon Spring Site}

by R. Van Lonkhuyzen, S. Yin, and I. Hohowskyj

Environmental Assessment Division,

Argonne National Laboratory, 9700 South Cass Avenue, Argonne, Illinois 60439

February 1995

Work sponsored by United States Department of Energy,

Oak Ridge Operations Office, Oak Ridge, Tennessee 
This report is printed on recycled paper. 


\section{CONTENTS}

NOTATION $\ldots \ldots \ldots \ldots \ldots \ldots \ldots \ldots \ldots \ldots \ldots \ldots \ldots \ldots \ldots \ldots \ldots \ldots \ldots \ldots$

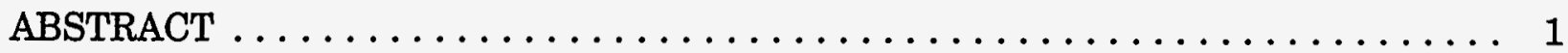

1 PROJECT PURPOSE AND DESCRIPTION $\ldots \ldots \ldots \ldots \ldots \ldots \ldots \ldots \ldots$

2 BORROW AREA AND HAUL ROAD CORRIDOR $\ldots \ldots \ldots \ldots \ldots \ldots \ldots$

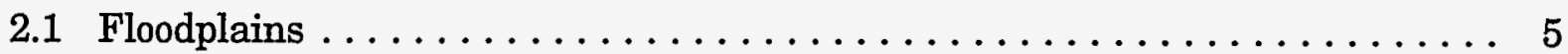

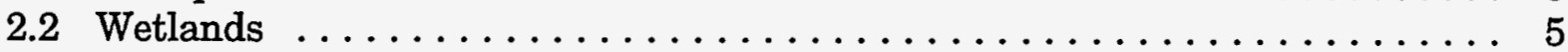

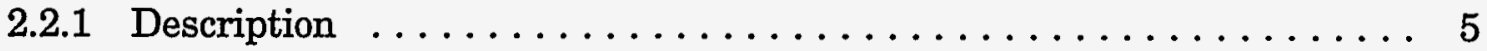

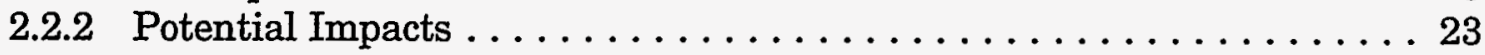

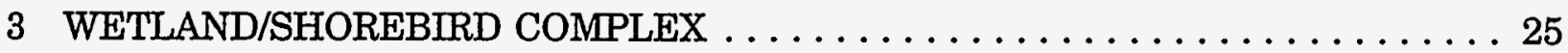

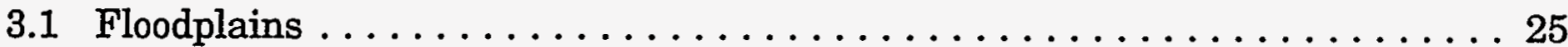

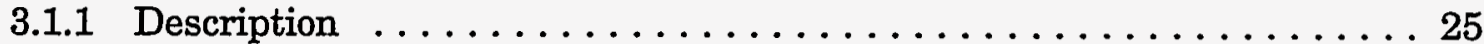

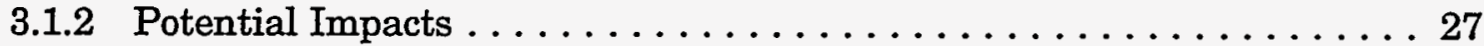

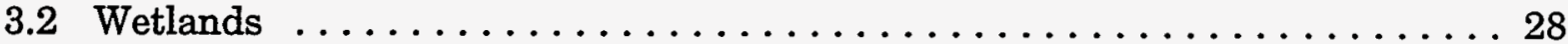

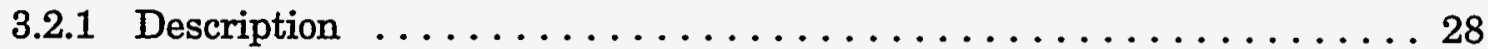

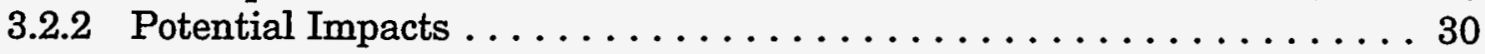

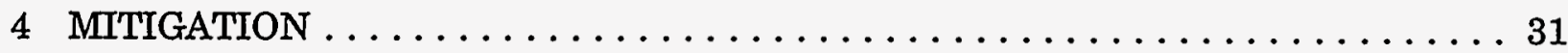

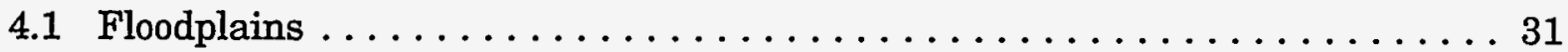

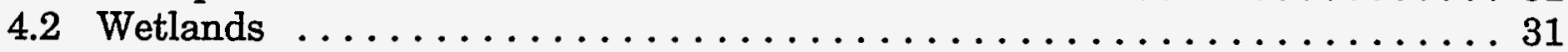

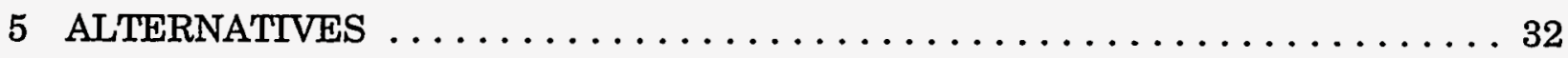

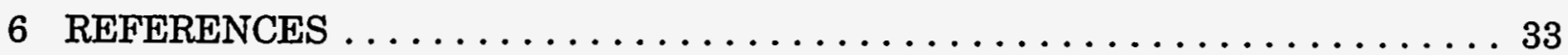

\section{FIGURES}

1 Location of the Weldon Spring Site $\ldots \ldots \ldots \ldots \ldots \ldots \ldots \ldots \ldots \ldots \ldots \ldots \ldots \ldots \ldots$

2 Wetlands Associated with the Borrow Area and Haul Road Corridor ........ 7

3 Diagram Showing Vegetation and Creekbed of Wetland A $\ldots \ldots \ldots \ldots 11$

4 Diagram Showing Vegetational Communities of Wetland B $\ldots \ldots \ldots 12$

5 Diagram Showing Vegetational Communities of Wetland $\mathrm{C} \ldots \ldots \ldots \ldots$

6 Diagram Showing Vegetational Communities of Wetland D ........... 15 


\section{FIGURES (Cont.)}

7 Diagram Showing Vegetational Communities and Open Water

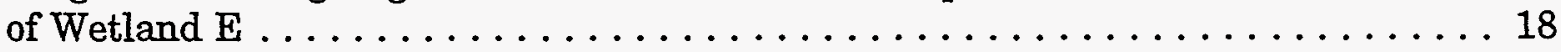

8 Diagram Showing Vegetational Community and Open Water of Wetland F . . . . . . . . . . . . . . . . . . . . . 20

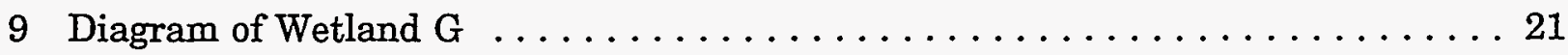

10 Diagram Showing Vegetational Community and Open Water of Wetland $\mathrm{H}$

11 Proposed Wetland/Shorebird Complex within the Busch

Conservation Area

12 Cross Section of Dardenne Creek Showing the Floodway

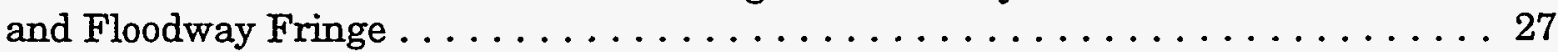

13 NWI Wetlands in the Vicinity of the Proposed Wetland/Shorebird Complex . . . 29

\section{TABLES}

1 List of Terrestrial and Aquatic Animal Species Known to Occur

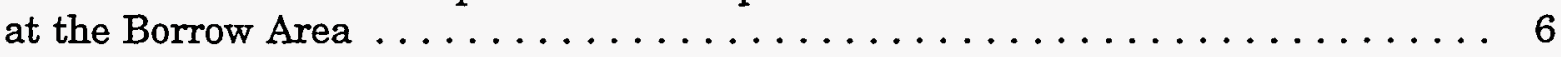

2 Dominant Plant Species of the Borrow Area and Haul Road Wetlands ....... 8

3 Dominant Plant Species and Indicator Status of Wetland A $\ldots \ldots \ldots \ldots 11$

4 Dominant Plant Species and Indicator Status of Wetland B . . . . . . . 12

5 Dominant Plant Species and Indicator Status of Wetland $C \ldots \ldots \ldots 13$

6 Dominant Plant Species and Indicator Status of Wetland D .......... 16

7 Dominant Plant Species and Indicator Status of Wetland $\mathrm{E} \ldots \ldots \ldots \ldots$

8 Dominant Plant Species and Indicator Status of Wetland F $\ldots \ldots \ldots \ldots$

9 Dominant Plant Species and Indicator Status of Wetland $G \ldots \ldots \ldots \ldots 21$

10 Dominant Plant Species and Indicator Status of Wetland H . . . . . . . 22

11 Dominant Wetland Plant Species of the Wetland/Shorebird Complex . . . . . . 29 


\section{NOTATION}

The following is a list of the acronyms, initialisms, and abbreviations (including units of measure) used in this document.

\section{ACRONYMS, INITIALISMS, AND ABBREVIATIONS}

CERCLA Comprehensive Environmental Response, Compensation, and Liability

DOE

EIS

FAC Act of 1980 , as amended

FACU

FACW U.S. Department of Energy environmental impact statement facultative plants facultative upland plants

FS facultative wetland plants

FWS feasibility study

NEPA U.S. Fish and Wildlife Service

NI

NWI

OBL

$\mathrm{RI}$ UPL National Environmental Policy Act of 1969, as amended no indicator status has been designated National Wetlands Inventory obligate wetland plants remedial investigation obligate upland plants

\section{UNITS OF MEASURE}

$\begin{array}{ll}\mathrm{ft} & \text { foot (feet) } \\ \mathrm{ha} & \text { hectare(s) } \\ \mathrm{km} & \text { kilometer(s) }\end{array}$

$\begin{array}{ll}\mathrm{m} & \text { meter(s) } \\ \mathrm{m}^{3} & \text { cubic meter(s) } \\ \mathrm{mi} & \text { mile(s) } \\ \mathrm{yd}^{3} & \text { cubic yard(s) }\end{array}$




\title{
A SURVEY OF THE WETLANDS AND FLOODPLAINS OF THE BORROW AREA AND WETLAND/SHOREBIRD COMPLEX FOR THE REMEDIAL ACTION - AT THE CHEMICAL PLANT AREA OF THE WELDON SPRING SITE
}

\author{
by
}

R. Van Lonkhuyzen, S. Yin, and I. Hlohowskyj

\begin{abstract}
The U.S. Department of Energy is conducting cleanup operations at the Weldon Spring site, St. Charles, Missouri, that will include development of a 77-ha (191-acre) soil borrow area. Eight wetlands, including riverine and palustrine emergent wetland types and totaling 0.9 ha ( 2.2 acres), will be eliminated during excavation of the borrow area. A 23-ha (57-acre) wetland/shorebird complex will be created at the Busch Conservation Area. The complex will include 2 ha ( 5 acres) of palustrine emergent wetland as mitigation for wetland losses in the borrow area.
\end{abstract}

\section{PROJECT PURPOSE AND DESCRIPTION}

The U.S. Department of Energy (DOE) is responsible for conducting remedial action activities at the Weldon Spring site under its Environmental Restoration and Waste Management Program. The Weldon Spring site is located in St. Charles County, Missouri, approximately $48 \mathrm{~km}$ (30 mi) west of St. Louis (Figure 1). The site and several small areas located on adjacent properties (vicinity properties) became radioactively and chemically contaminated as a result of processing and disposal activities that occurred from the 1940s to the 1960s. The site is listed on the National Priorities List of the U.S. Environmental Protection Agency (1987, 1989, 1990).

The DOE is responsible for those areas radioactively contaminated as a result of uranium-processing activities at the Weldon Spring site. The removal, treatment, and disposal of the contaminated sediments, sludges, and soils from the site and vicinity properties is necessary to minimize the potential for impacts to human health and the environment and to complete overall site remediation. An integrated remedial investigation/ feasibility study-environmental impact statement (RI/FS-EIS) was prepared to support the cleanup decisions for the chemical plant area (DOE 1992a-e, 1993a). A Record of Decision was prepared to document DOE's decision under both the Comprehensive Environmental Response, Compensation, and Liability Act (CERCLA) and the National Environmental Policy Act (NEPA) that the preferred remedy for the chemical plant area of the Weldon Spring site is removal, chemical stabilization/solidification, and on-site disposal (DOE 1993b). 


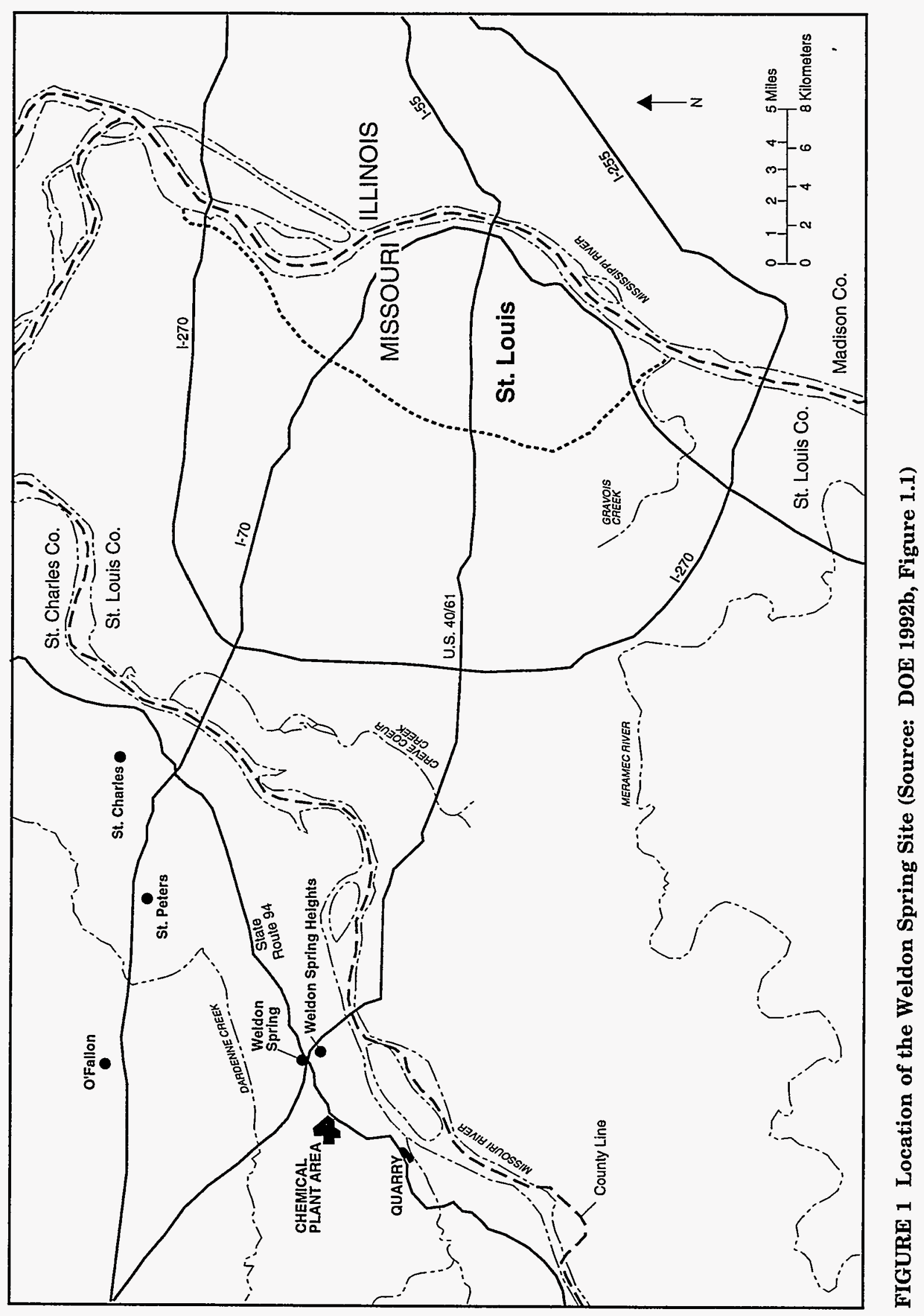


Cleanup of the Weldon Spring site will require the excavation, treatment, and disposal of approximately $675,000 \mathrm{~m}^{3}\left(883,000 \mathrm{yd}^{3}\right)$ of contaminated sludge, sediment, soil and other materials (DOE 1992b). About $342,000 \mathrm{~m}^{3}\left(447,000 \mathrm{yd}^{3}\right)$ of contaminated media and materials will be treated by chemical stabilization/solidification to reduce contaminant mobility, facilitate waste handling, and eliminate free water (DOE 1992b). In addition, the volume of some of the treated and untreated materials will be reduced, as appropriate. Following treatment and volume reduction, the treated and untreated materials will be placed in an on-site engineered disposal cell.

Construction of an on-site disposal cell will require an esțimated 1.9 million $\mathrm{m}^{3}$ (2.5 million $\mathrm{yd}^{3}$ ) of clean, uncontaminated fill (borrow) material. This material will be removed from a 77-ha (191-acre) tract located in the Weldon Spring Conservation Area, approximately $1.5 \mathrm{~km}$ (1.0 mi) east of the chemical plant area. This land is owned by the Missouri Department of Conservation. Associated with the borrow area will be a 14-ha (35-acre) haul road corridor for transporting the borrow material to the disposal cell. Borrow operations are expected to continue incrementally for about seven years, with soils being removed to a maximum depth of $6.7 \mathrm{~m}(22 \mathrm{ft})$, as needed. At the end of each year, the excavated areas will be reclaimed. To excavate the needed borrow, existing ponds and wetlands within the borrow area will be drained and all vegetation from the site will be cleared.

The excavation and construction activities for remediation of the Weldon Spring site will adversely impact wetland and floodplain areas. Impacts to floodplains and wetlands at the chemical plant area were evaluated in the RI/FS-EIS, and a separate wetlands/floodplain assessment was prepared for the activities affecting those areas (see Appendix $\mathrm{H}$ of the FS; DOE 1992b). The current survey was prepared to address the potential for floodplain and wetland impacts that might occur as a result of the excavation of borrow material and the construction of the haul road corridor connecting the chemical plant area and borrow area.

In the course of preparing the RI/FS-EIS, DOE initiated consultations with the U.S. Army Corps of Engineers for a determination of the status of the on-site wetlands and the need for any wetland permits that would be required for compliance with Section 404 of the Clean Water Act (Hlohowskyj 1990). The Corps of Engineers determined that no permits for wetland filling or draining activities would be needed for the on-site wetlands because they occur within the boundary of a National Priorities List site and are thus exempt from the requirements of Section 404 of the Clean Water Act (Jewett 1990). The DOE has received a Section 404 permit authorization from the Corps of Engineers for the proposed activities at the borrow area and haul road corridor.

The DOE (McCracken 1991a) also initiated consultations with the U.S. Fish and Wildlife Service (FWS) regarding the need for mitigation of the on-site wetlands that will be permanently lost as a result of remedial activities at the site. The FWS urged DOE to consider wetland creation as a means of mitigating the loss of the on-site wetlands and aquatic habitats (Brabander 1991). The DOE committed to developing mitigation for the chemical plant area wetlands (McCracken 1991b) and has developed a mitigation plan in 
cooperation and consultation with the Missouri Department of Conservation (Crigler 1993; MK-Ferguson Company and Jacobs Engineering Group 1994). The FWS has given its support to the wetland mitigation as proposed in the plan (Brabander 1994). The plan also includes mitigation for wetland impacts associated with the borrow area and haul road corridor and satisfies mitigation for loss of on-site wetlands and aquatic habitats at the chemical plant area, as stated in the site Record of Decision (DOE 1993b). The wetland mitigation plan includes the construction of a 23 -ha (57-acre) seasonally flooded wetland/ shorebird complex within the Busch Conservation Area and includes approximately 2 ha (5 acres) of replacement wetlands to mitigate for the loss of wetlands at the borrow area and haul road, as required for compliance with Section 404 of the Clean Water Act and the Nationwide Permit 26 issued by the U.S. Army Corps of Engineers (Jewett 1994). The current survey evaluates potential impacts to floodplain and wetland areas within the proposed wetland/shorebird complex. 


\section{BORROW AREA AND HAUL ROAD CORRIDOR}

The borrow area and haul road corridor are located within the August A. Busch Complex, which includes the Busch Conservation Area and the Weldon Spring Conservation Area. The complex is managed by the Missouri Department of Conservation for recreation and wildlife. The Busch Conservation Area to the north and west contains 33 lakes and 60 ponds, mostly man-made and totaling 218 surface ha (539 surface acres) of water, along with some intermittent streams (Missouri Department of Conservation 1989). The Weldon Spring Conservation Area contains a large number of intermittent and perennial streams to the south and west, which are tributary to the Missouri River about $1.6 \mathrm{~km}$ (1 mi) to the south of the borrow area. Also located within the Weldon Spring Conservation Area are 12 ponds, 2 lakes, and 5 springs (Missouri Department of Conservation 1989).

\subsection{FLOODPLAINS}

Flood Insurance Rate Maps for St. Charles County (Federal Insurance Administration 1978a-c) were used to identify the occurrence of floodplains at the borrow area and along the haul road corridor. No 100-year floodplains were identified at these areas.

\subsection{WETLANDS}

Wetlands provide important habitat for many wildlife species. Terrestrial vertebrate species that are known to occur in the borrow area and might use the wetlands include Branta canadensis, Anas platyrhynchos, Ardea herodias, Charadrius vociferus, Agelaius phoeniceus, Odocoileus virginianus, and Procyon lotor (Table 1). Aquatic animal species known to occur in the borrow area include Chelydra serpentina serpentina, Trachemys scripta elegans, Acris crepitans blanchardi, Rana catesbeiana, Cambarus sp., Lepomis macrochirus, Micropterus salmoides, Gambusia affinis, Opsopoeodus emiliae, Lepomis microlophus, Ictalurus punctatus, Pylodictus olivarus, and Ctenopharyngodon idella (Table 1).

National Wetlands Inventory (NWI) maps (FWS 1989), aerial photographs, and site visits by ecologists from Argonne National Laboratory were used to identify the occurrence of wetlands at the borrow area and along the haul road corridor. The wetlands within the project area were delineated during the spring and summer of 1993 on the basis of the 1987 federal guidelines for wetland delineation (Environmental Laboratory 1987). To qualify as wetland under these guidelines, an area must have hydrophytic vegetation, wetland hydrology, and hydric soil. Areas that met the three criteria for jurisdictional wetland were mapped from black and white aerial photography.

\subsubsection{Description}

The borrow area and haul road corridor contain eight wetlands, which range in size from 0.03 to $0.47 \mathrm{ha}$ ( 0.07 to 1.17 acre) and include a total of $0.9 \mathrm{ha}$ ( 2.2 acres). Five of these 


\section{TABLE 1 List of Terrestrial and Aquatic Animal Species Known to Occur at the Borrow Area}

\begin{tabular}{ll}
\hline \multicolumn{1}{c}{ Scientific Name } & \multicolumn{1}{c}{ Common Name } \\
\hline Invertebrates & \\
Cambarus sp. & Crayfish \\
Fish & \\
Ctenopharyngodon idella & Grass carp \\
Gambusia affinis & Mosquitofish \\
Ictalurus punctatus & Channel catfish \\
Lepomis macrochirus & Bluegill \\
Lepomis microlophus & Redear sunfish \\
Micropterus salmoides & Largemouth bass \\
Opsopoeodus emiliae & Pugnose minnow \\
Pylodictus olivarus & Flathead catfish \\
Reptiles and Amphibians & \\
Acris crepitans blanchardi & Cricket frog \\
Chelydra serpentina serpentina & Common snapping turtle \\
Rana catesbeiana & Bullfrog \\
Trachemys scripta elegans & Red-eared slider \\
Birds & \\
Agelaius phoeniceus & Red-winged blackbird \\
Anas platyrhynchos & Mallard \\
Ardea herodias & Great blue heron \\
Branta canadensis & Canada goose \\
Charadrius vociferus & Killdeer \\
Mammals & \\
Odocoileus virginianus & White-tailed deer \\
Procyon lotor & Raccoon \\
\hline
\end{tabular}

Source: Reitinger (1992).

wetlands appear on the NWI map for the area (FWS 1989). These NWI-listed wetlands are man-made, created by damming of some of the small intermittent streams that originate within the borrow area and haul road corridor. Figure 2 shows the eight wetlands (A through $\mathrm{H}$ ) and four additional NWI-listed wetlands ( $\mathrm{I}$ through $\mathrm{L}$ ) that are located outside the project area but receive drainage directly from it.

Most of the wetlands are palustrine, being small nontidal wetlands in shallow still water or variably flooded areas (Cowardin et al. 1979). Other wetlands within the project area are riverine, occurring within intermittent stream channels. A complete list of dominant species found at the borrow area and haul road wetlands is presented in Table 2. A description of each wetland follows, including a figure and table showing the vegetative 


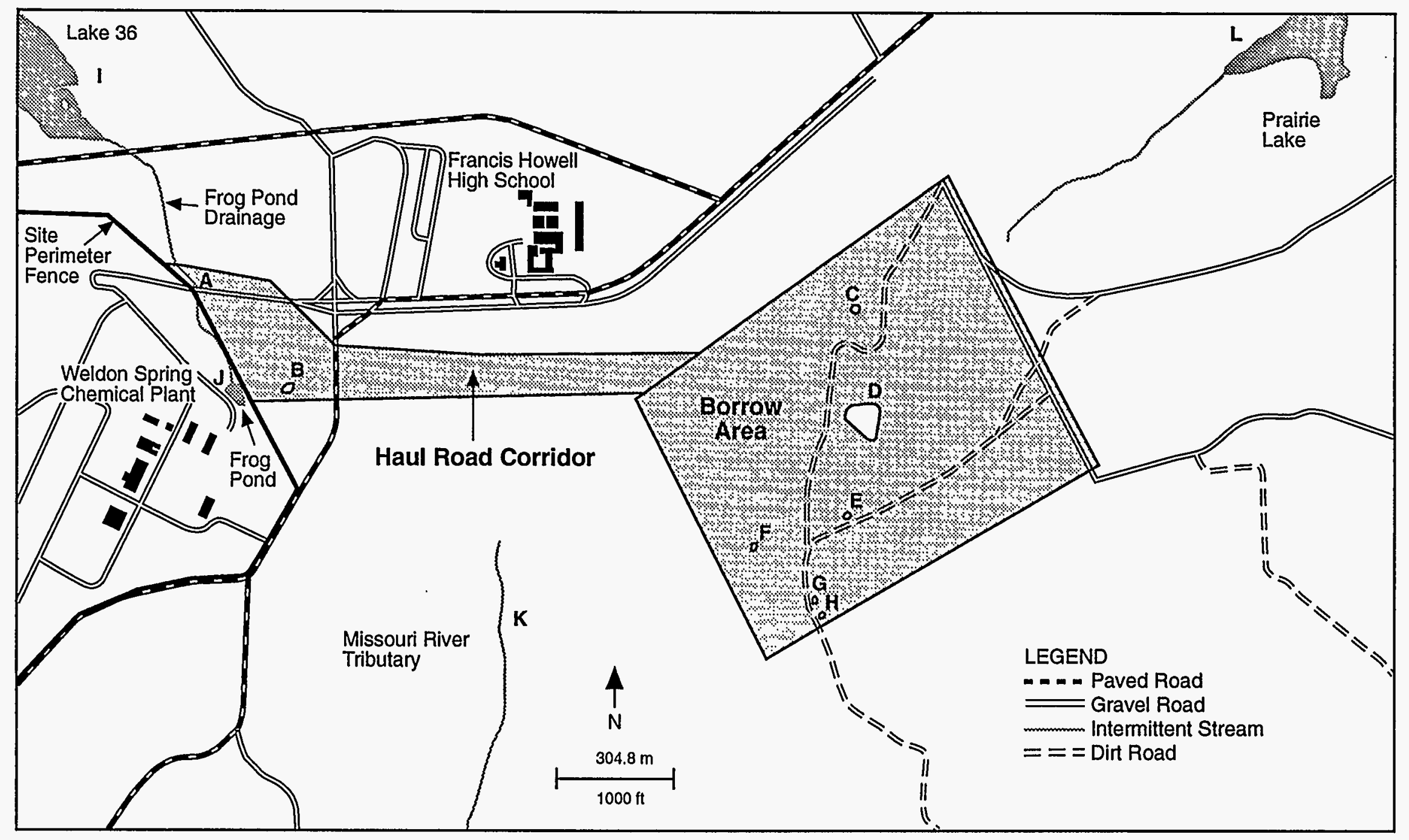

FIGURE 2 Wetlands Associated with the Borrow Area and Haul Road Corridor 
TABLE 2 Dominant Plant Species of the Borrow Area and Haul Road Wetlands

\begin{tabular}{|c|c|c|}
\hline Scientific $\mathrm{Name}^{\mathrm{a}}$ & Common Name & Frequency ${ }^{\mathrm{b}}$ \\
\hline Acer saccharinum & Silver maple & 3 \\
\hline Agalinis tenuifolia & Slender false-foxglove & 1 \\
\hline Agrostis alba & Redtop & 2 \\
\hline Agrostis perennans & Perennial bent grass & 1 \\
\hline Alisma plantago-aquatica & Broad-leaf water-plantain & 2 \\
\hline Ammannia coccinea & Purple ammannia & 1 \\
\hline Bidens frondosa & Devil's beggar-ticks & 1 \\
\hline Bidens polylepis & Awnless beggar-ticks & 15 \\
\hline Boehmeria cylindrica & Small-spike false-nettle & 1 \\
\hline Carex frankii & Frank's sedge & 6 \\
\hline Carex normalis & Larger straw sedge & 4 \\
\hline Carex shortiana & Short's sedge & 1 \\
\hline Carex tribuloides & Blunt broom sedge & 2 \\
\hline Carex vulpinoidea & Fox sedge & 10 \\
\hline Celtis occidentalis & Common hackberry & 1 \\
\hline Cyperus strigosus & Straw-color flatsedge & 2 \\
\hline Diospyros virginiana & Common persimmon & 2 \\
\hline Echinochloa muricata & Rough barnyard grass & 15 \\
\hline Eleocharis acicularis & Least spikerush & 1 \\
\hline Eleocharis obtusa & Blunt spikerush & 14 \\
\hline Eleocharis smallii & Small's spikerush & 4 \\
\hline Eupatorium serotinum & Late-flowering thorough-wort & 2 \\
\hline Festuca pratensis & Meadow fescue & 6 \\
\hline Geum canadense & White avens & 1 \\
\hline Gleditsia triacanthos & Honey-locust & 1 \\
\hline Gratiola neglecta & Clammy hedgehyssop & 1 \\
\hline Helianthus grosseserratus & Saw-tooth sunflower & 1 \\
\hline Impatiens capensis & Spotted touch-me-not & 1 \\
\hline Juncus interior & Inland rush & 5 \\
\hline Juncus marginatus & Grass-leaf rush & 1 \\
\hline Leersia oryzoides & Rice cutgrass & 14 \\
\hline Lemna minor & Lesser duckweed & 2 \\
\hline Lobelia siphilitica & Great blue lobalia & 1 \\
\hline Ludwigia peploides & Floating seedbox & $\overline{4}$ \\
\hline Mimulus alatus & Sharp-wing monkey-flower & 2 \\
\hline Morus alba & White mulberry & 2 \\
\hline Poa pratensis & Kentucky bluegrass & 2 \\
\hline Polygonum hydropiper & Marshpepper smartweed & 1 \\
\hline Polygonum hydropiperoides & Swamp smartweed & 1 \\
\hline Polygonum pensylvanicum & Pennsylvania smartweed & 4 \\
\hline Polygonum punctatum & Dotted smartweed & 9 \\
\hline Potamogeton nodosus & Long-leaf pondweed & 2 \\
\hline Rubus alumnus & Old field blackberry & 1 \\
\hline Rumex acetosella & Sheep sorrel & 1 \\
\hline Salix nigra & Black willow & 5 \\
\hline Scirpus atrovirens & Green bulrush & 5 \\
\hline Setaria faberi & Japanese bristle grass & 1 \\
\hline Setaria glauca & Yellow bristle grass & 1 \\
\hline
\end{tabular}


TABLE 2 (Cont.)

\begin{tabular}{llc}
\hline \multicolumn{1}{c}{ Scientific Name ${ }^{\mathrm{a}}$} & \multicolumn{1}{c}{ Common Name } & Frequency $^{\mathrm{b}}$ \\
\hline Solidago canadensis & Canada golden-rod & 2 \\
Teucrium canadense & American germander & 1 \\
Thlaspi arvense & Field penny-cress & 1 \\
Toxicodendron radicans & Poison ivy & 6 \\
Ulmus americana & American elm & 2 \\
Xanthium strumarium & Rough cockle-bur & 2 \\
\hline \multicolumn{3}{l}{ a Nomenclature follows Reed (1988). } \\
b Number of communities in which the species was a dominant.
\end{tabular}

communities within each wetland and the indicator status of the dominant plant species. The indicator status of the dominant plant species was based on Reed (1988), as follows:

- Obligate wetland plants (OBL) are plants that occur almost always in wetlands under natural conditions (estimated probability $>99 \%$ ), but may also occur rarely in nonwetlands (estimated probability $<1 \%$ ).

- Facultative wetland plants (FACW) are plants that occur usually in wetlands (estimated probability 67 to 99\%), but also occur in nonwetlands (estimated probability 1 to $33 \%$ ).

- Facultative plants (FAC) are plants with a similar likelihood of occurring in both wetlands and nonwetlands (estimated probability 34 to $66 \%$ ).

- Facultative upland plants (FACU) are plants that occur sometimes in wetlands (estimated probability 1 to $33 \%$ ), but occur more often in nonwetlands (estimated probability 67 to $99 \%$ ).

- Obligate upland plants (UPL) are plants that occur rarely in wetlands (estimated probability $<1 \%$ ), but occur almost always in nonwetlands under natural conditions (estimated probability $>99 \%$ ).

The three facultative categories may be subdivided by "+" (more likely to occur in wetlands) or "-" (less likely to occur in wetlands); an indicator status of NI means that no indicator has yet been assigned to that species (Environmental Laboratory 1987).

Wetland A occurs along the banks and on islands within the channel of an intermittent stream, known as the Frog Pond Drainage, in the extreme northwest corner of the haul road corridor (Figure 2). Approximately $110 \mathrm{~m}$ (350 ft) of this channel occurs within the haul road corridor, including approximately 0.04 ha (0.09 acre) of wetland. The banks 
are about 1.2 to $1.5 \mathrm{~m}$ ( 4 to $5 \mathrm{ft}$ ) high and relatively steep. The wetland community reaches from the streambed to about $0.600 .9 \mathrm{~m}$ ( 2 to $3 \mathrm{ft}$ ) up the sides of the bank (Figure 3 ). The portion occurring within the streambed would be classified as riverine, whereas the portion on the banks would be classified as palustrine. Vegetation in this wetland includes Ulmus americana, Impatiens capensis, and Geum canadense (Table 3). Flowing water is present for most of the growing season. Soils were not sampled at this site because of known contamination. The channel receives drainage from wetland $J$ (known as Frog Pond), approximately $250 \mathrm{~m}$ (825 ft) south of wetland $\mathrm{A}$, and drains into wetland I (Busch Conservation Area lake 36), approximately $380 \mathrm{~m}(1,250 \mathrm{ft})$ northwest of wetland A (Figure 2). Neither wetland $\mathrm{I}$ or $\mathrm{J}$ are within the borrow area and haul road corridor. The surrounding upland areas are deciduous forest, with an unused road and the DOE property fence crossing the stream channel.

Wetland B is located within the western portion of the haul road corridor (Figure 2). It appears on the NWI map as "palustrine, unconsolidated bottom, intermittently exposed, diked/impounded." This wetland consists of an outer community and an inner community within a small, shallow pond that was created by placement of an earthen embankment across an intermittent stream (Figure 4). The outer community is inundated in spring and becomes merely saturated during the summer as the pond waters recede; emergent vegetation in this community includes Carex vulpinoidea, Juncus spp., Leersia oryzoides; and Eleocharis spp. (Table 4). The inner community includes the interior portion of the pond and remains inundated through most of the growing season; dominants in this community include Eleocharis spp., Leersia oryzoides, Lemna minor, and Polygonum hydropiperoides (Table 4). Soils at wetland $B$ are hydric, based on a low chroma matrix color (10YR4/2, mottled) and an aquic moisture regime (Environmental Laboratory 1987). Wetland B, about 0.04 ha (0.09 acre) in size, receives surface runoff from the surrounding upland areas and contributes to drainage into wetland J. Surrounding upland areas are mostly deciduous forest, with a parking/maintenance area to the southeast.

Wetland $\mathrm{C}$, about $0.13 \mathrm{ha}(0.33$ acre $)$ in size, is located in the north-central portion of the borrow area (Figure 2). It appears on the NWI map as "palustrine, unconsolidated bottom, intermittently exposed, diked/impounded." This wetland contains a small pond, about 0.3 ha $(0.8$ acre) in size (Figure 5), that was created by placement of an earthen embankment across a small intermittent stream. Wetland $\mathrm{C}$ receives surface runoff from the surrounding upland areas and a small drainage to the south. It drains, via seepage through and around the embankment, into an intermittent stream to the north. Emergent vegetation around the pond fringe where the slope is gradual consists of two communities. The outermost community (community 1) supports Carex spp., Scirpus atrovirens, and Juncus interior; the inner community (community 2) supports Ludwigia peploides, Leersia oryzoides, Eleocharis obtusa, and Potamogeton nodosus (Table 5). The vegetation forms a zone approximately $5 \mathrm{~m}$ (16.4 ft) in width around the pond. The outer community is shallowly inundated early in the growing season but becomes merely saturated as the pond level drops during the summer. The inner community remains inundated throughout most of the growing season. Along the embankment, where the slope is steep, one narrow community 


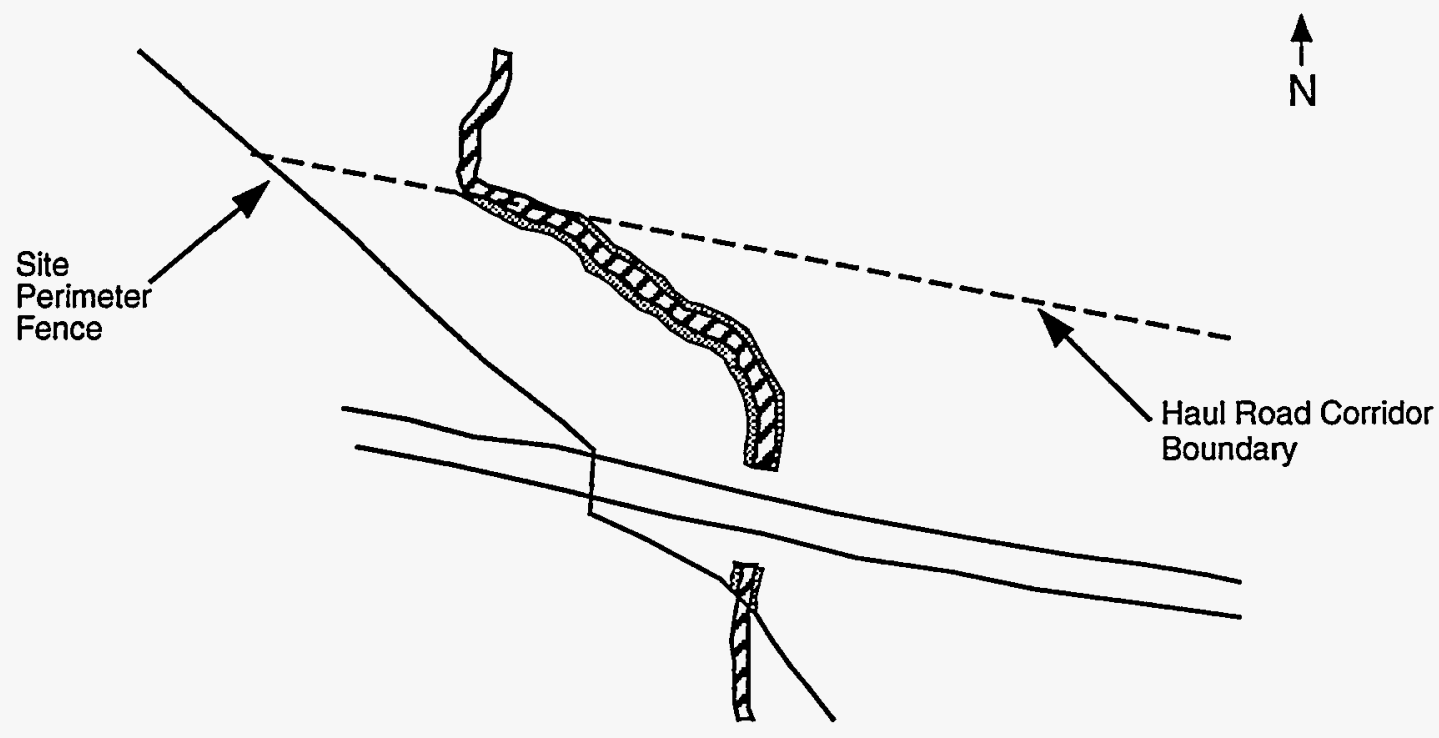

Wetland Community

$\square$ Creekbed

$\frac{30 \mathrm{~m}}{100 \mathrm{ft}}$

FIGURE 3 Diagram Showing Vegetation and Creekbed of Wetland A

TABLE 3 Dominant Plant Species and Indicator Status of Wetland A

\begin{tabular}{ll}
\hline Dominant Species & $\begin{array}{c}\text { Wetland } \\
\text { Indicator Status }\end{array}$ \\
\hline Geum canadense & FAC \\
Impatiens capensis & FACW \\
Ulmus americana & FACW- \\
\hline
\end{tabular}


Wetland Communities
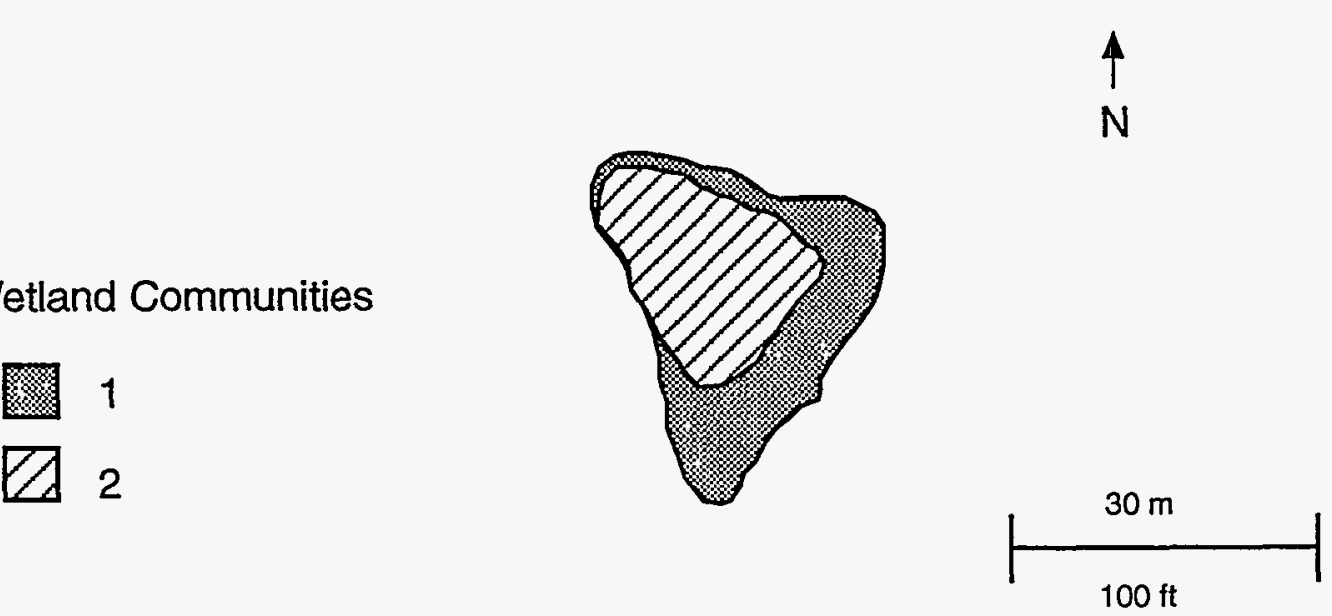

FIGURE 4 Diagram Showing Vegetational Communities of Wetland B

TABLE 4 Dominant Plant Species and Indicator Status of Wetland B

\begin{tabular}{cc}
\hline Dominant Species & $\begin{array}{c}\text { Wetland } \\
\text { Indicator Status }\end{array}$ \\
\hline Community 1 & \\
Agrostis perennans & FAC- \\
Carex vulpinoidea & OBL \\
Eleocharis obtusa & OBL \\
Eleocharis smallii & OBL \\
Juncus interior & FAC+ \\
Juncus marginatus & FACW \\
Leersia oryzoides & OBL \\
& \\
Community 2 & \\
Eleocharis obtusa & OBL \\
Eleocharis smallii & OBL \\
Leersia oryzoides & OBL \\
Lemna minor & OBL \\
Polygonum hydropiperoides & OBL \\
\hline
\end{tabular}




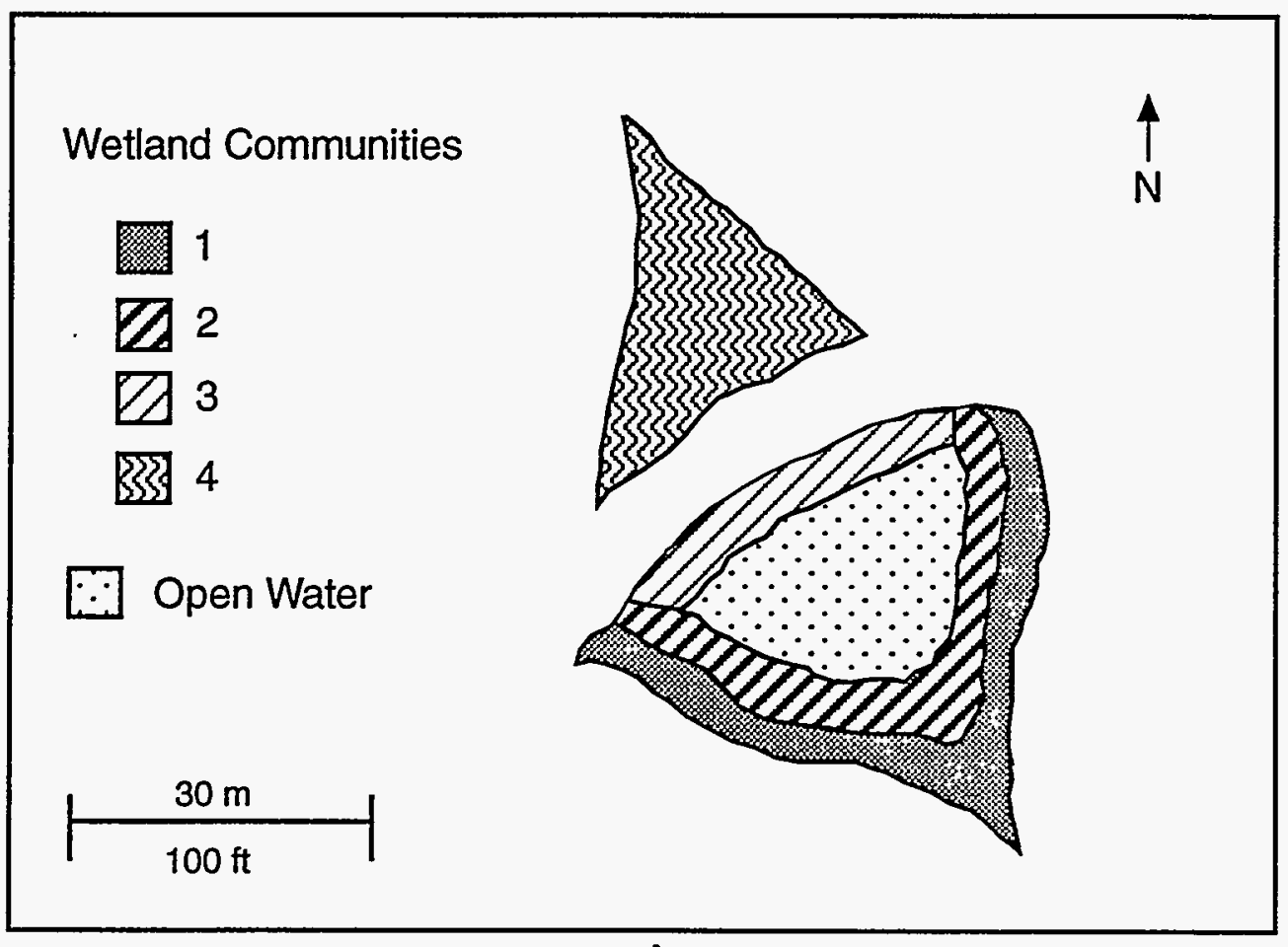

FIGURE 5 Diagram Showing Vegetational Communities of Wetland C

TABLE 5 Dominant Plant Species and Indicator Status of Wetland C

\begin{tabular}{llll}
\hline \multicolumn{1}{c}{ Dominant Species } & $\begin{array}{c}\text { Wetland } \\
\text { Indicator } \\
\text { Status }\end{array}$ & Dominant Species & $\begin{array}{c}\text { Wetland } \\
\text { Indicator } \\
\text { Status }\end{array}$ \\
\hline $\begin{array}{l}\text { Community 1 } \\
\text { Bidens polylepis }\end{array}$ & FACW & $\begin{array}{c}\text { Community } 3 \\
\text { Bidens polylepis }\end{array}$ & FACW \\
Carex frankii & OBL & Carex frankii & OBL \\
Carex normalis & FACW & Leersia oryzoides & OBL \\
Carex vulpinoidea & FACW+ & Ludwigia peploides & OBL \\
Cyperus strigosus & OBL & Morus alba & FAC \\
Eleocharis obtusa & FACW & Salix nigra & OBL \\
Juncus interior & OBL & Community 4 & \\
Scirpus atrovirens & FAC+ & EBL & OBL \\
Toxicodendron radicans & FAC+ & Helianthus grosseserratus & FACW- \\
& & Polygonum punctatum & OBL \\
Community 2 & Setaria faberi & FACU+ \\
Alisma plantago-aquatica & OBL & Solidago canadensis & FACU \\
Eleocharis obtusa & OBL & Thlaspi arvense & NI \\
Leersia oryzoides & OBL & & \\
Ludwigia peploides & OBL & & \\
Potamogeton nodosus & OBL & & \\
Salix nigra & OBL & & \\
\hline
\end{tabular}


(community 3) occurs that remains inundated most of the growing season; dominants include Leersia oryzoides, Ludwigia peploides, and Salix nigra. The drainage out (community 4) supports Helianthus grosseserratus, Polygonum punctatum, Solidago canadensis, Echinochloa muricata, and Setaria faberi. The embankment supports upland grasses and woody species including Salix nigra. Otherwise, the surrounding upland area is grassy old-field. Soils at wetland $\mathrm{C}$ are hydric, based on a low chroma matrix color (10YR4/1, 10YR3/1.5, 10YR3/2; all mottled) (Environmental Laboratory 1987).

Wetland D is located in the central portion of the borrow area (Figure 2), and it encompasses a perennial pond, Missouri Department of Conservation pond WSP-A (Figure 6). The total surface area is about 0.8 ha ( 2 acres) in size and appears on the NWI map as "palustrine, unconsolidated bottom, intermittently exposed, diked/impounded." The pond was created by placement of an earthen embankment across an intermittent stream. It receives surface runoff from the surrounding upland areas and discharge from two small intermittent streams. It drains, via seepage through and around the embankment, into an intermittent stream that drains into wetland $\mathrm{L}$ (Prairie Lake). Wetland $\mathrm{L}$ is not located within the borrow area and haul road corridor.

The shallow water areas around the edge of the pond, where the ground slopes gradually, support emergent vegetation consisting of two communities. The outer community (community 1) supports Juncus interior, Agrostis alba, Bidens polylepis, Echinochloa muricata, and Carex vulpinoidea; the inner community (community 2) supports Eleocharis spp., Leersia oryzoides, Ludwigia peploides, and Potamogeton nodosus (Table 6). This emergent vegetation forms a zone approximately $5 \mathrm{~m}(16.4 \mathrm{ft})$ in width. Where the slope is steep along the embankment, a narrow zone supports one community (community 3) that includes Acer saccharinum, Toxicodendron radicans, Leersia oryzoides, and Salix nigra. Small sapling Salix nigra are common in the emergent community on the northwest side and along the embankment on the east side (community 3). The outer community is shallowly inundated early in the growing season but becomes merely saturated as the pond level drops during the summer. The inner community and the zone along the embankment remain inundated throughout most of the growing season. Several small wetland communities that are shallowly inundated early in the growing season are located near the pond in upstream drainages (communities 4 to 9 ) and below the embankment in downstream drainages (communities 10 to 12). The drainage out supports Carex spp., Bidens polylepis, Echinochloa muricata, and Scirpus atrovirens, whereas the drainages into the pond support Carex spp., Eleocharis spp., Echinochloa muricata, Polygonum spp., and Bidens polylepis.

The soils at wetland D are hydric, based on a low chroma matrix color (2.5Y4/2, 5Y4/1, 10YR3.5/1.5, 10YR4/2, 10YR4/1, 10YR4.5/2, 10YR5/2; all mottled) (Environmental Laboratory 1987). The total wetland area is approximately 0.47 ha (1.17 acres). The embankment is overgrown with woody vegetation including Salix nigra, Toxicodendron radicans, and Acer negundo. Otherwise the surrounding area is grassy old-field. The immediately surrounding upland area is maintained by the Missouri Department of Conservation for recreational access to the pond and is occasionally mowed northwest and southwest of the pond. The pond is identified by the Missouri Department of Conservation as a multiple-species fishing water (Missouri Department of Conservation 1989). 


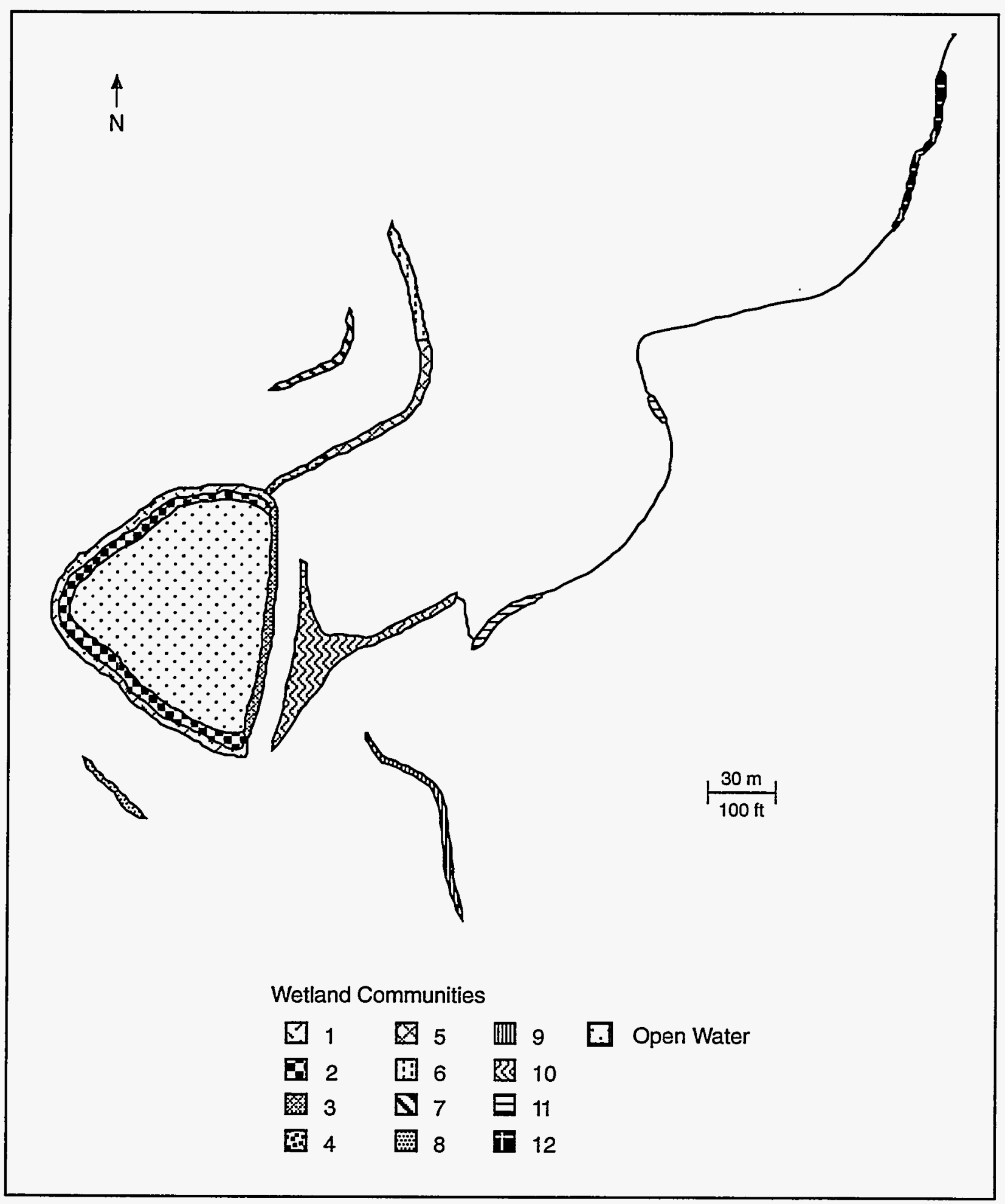

FIGURE 6 Diagram Showing Vegetational Communities of Wetland $D$ 
TABLE 6 Dominant Plant Species and Indicator Status of Wetland D

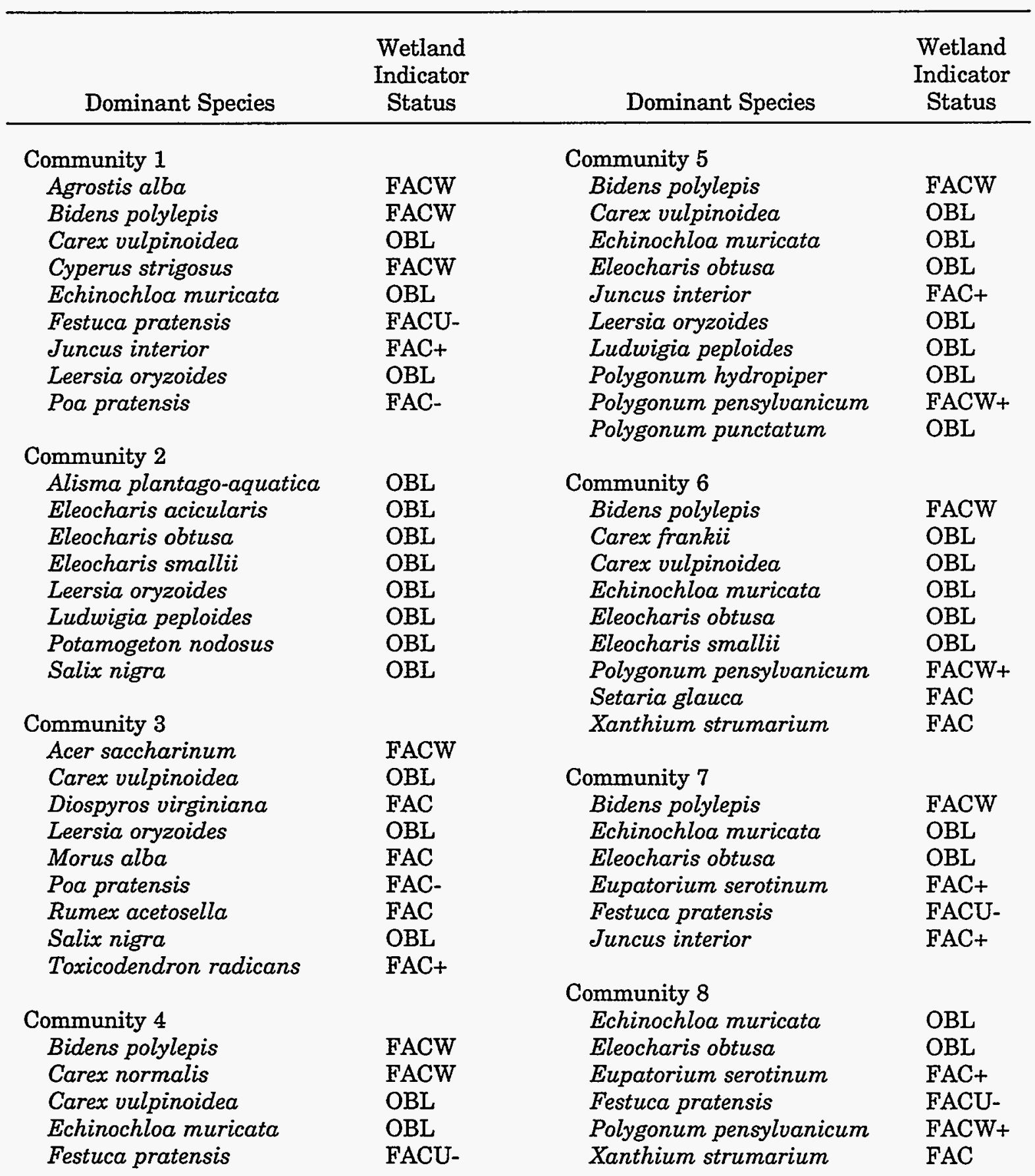


TABLE 6 (Cont.)

\begin{tabular}{llll} 
& Wetland & & Wetland \\
\multicolumn{1}{c}{ Dominant Species } & Indicator & & Indicator \\
Status & Dominant Species & Status \\
\hline Community 9 & & Community 11 & \\
Ammannia coccinea & OBL & Bidens polylepis & FACW \\
Bidens polylepis & FACW & Carex frankii & OBL \\
Echinochloa muricata & OBL & Carex vulpinoidea & OBL \\
Eleocharis obtusa & OBL & Echinochloa muricata & OBL \\
Gratiola neglecta & OBL & Eleocharis obtusa & OBL \\
Polygonum pensylvanicum & FACW+ & Festuca pratensis & FACU- \\
Polygonum punctatum & OBL & Leersia oryzoides & OBL \\
& & Mimulus alatus & OBL \\
Community 10 & Polygonum punctatum & OBL \\
Agrostis alba & FACW & & \\
Bidens polylepis & FACW & Community 12 & \\
Carex frankii & OBL & Bidens polylepis & FACW \\
Carex normalis & FACW & Carex frankii & OBL \\
Carex shortiana & FACW+ & Carex normalis & FACW \\
Carex tribuloides & FACW+ & Carex vulpinoidea & OBL \\
Carex vulpinoidea & OBL & Echinochloa muricata & OBL \\
Celtis occidentalis & FAC- & Festuca pratensis & FACU- \\
Diospyros virginiana & FAC & Lobelia siphilitica & FACW+ \\
Echinochloa muricata & OBL & Mimulus alatus & OBL \\
Gleditsia triacanthos & FAC & Rubus alumnus & FAC- \\
Leersia oryzoides & OBL & Scirpus atrovirens & OBL \\
Scirpus atrovirens & OBL & Teucrium canadense & FACW- \\
Solidago canadensis & FACU & & \\
Toxicodendron radicans & FAC+ & & \\
\hline
\end{tabular}

Wetland $E$ is located within the south-central portion of the borrow area (Figure 2). It appears on the NWI map as "palustrine, unconsolidated bottom, intermittently exposed, diked/impounded." This wetland encompasses a small pond about 0.12 ha (0.3 acre) in size (Figure 7). The pond was created by placement of an earthen embankment across an intermittent stream. It receives surface runoff from the surrounding upland areas, which are grassy and shrubby old-field. The wetland drains to the southeast, via seepage through and around the embankment, into an intermittent tributary to the Missouri River. Emergent vegetation around the pond fringe (community 1) includes Leersia oryzoides and Scirpus atrovirens, in a zone about $5 \mathrm{~m}$ (16.4 ft) wide (Table 7), which is inundated throughout the growing season. A small wetland community (community 2) immediately north and upgradient of the pond is inundated early in the growing season and supports Bidens polylepis, Echinochloa muricata, and Polygonum punctatum; the drainage out (community 3) supports Leersia oryzoides and Polygonum punctatum (Table 7) and is also inundated early in the growing season. The total wetland area is approximately 0.08 ha $(0.21$ acre). The soils at wetland $\mathrm{E}$ are hydric, based on a low chroma matrix color (10YR4/2, mottled) (Environmental Laboratory 1987). 


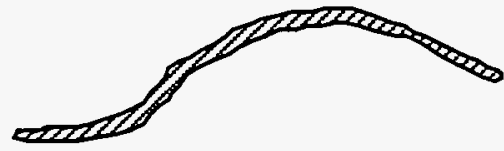

Wetland Communities

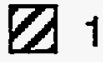

2

BSS 3

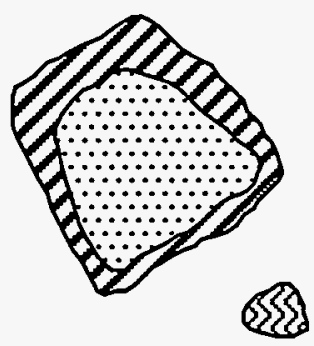

$\because:$ Open Water

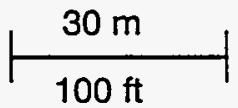

FIGURE 7 Diagram Showing Vegetational Communities and Open Water of Wetland E

TABLE 7 Dominant Plant Species and Indicator Status of Wetland E

\begin{tabular}{llll}
\hline Dominant Species & $\begin{array}{c}\text { Wetland } \\
\text { Indicator } \\
\text { Status }\end{array}$ & Dominant Species & $\begin{array}{c}\text { Wetland } \\
\text { Indicator } \\
\text { Status }\end{array}$ \\
\hline Community 1 & & Community 3 & \\
Bidens polylepis & FACW & Bidens polylepis & FACW \\
Echinochloa muricata & OBL & Echinochloa muricata & OBL \\
Leersia oryzoides & OBL & Leersia oryzoides & OBL \\
Polygonum punctatum & OBL & Polygonum punctatum & OBL \\
Scirpus atrovirens & OBL & & \\
Community 2 & & & \\
Bidens polylepis & FACW & & \\
Echinochloa muricata & OBL & & \\
Eleocharis obtusa & OBL & & \\
Leersia oryzoides & OBL & & \\
Polygonum punctatum & OBL & & \\
\hline
\end{tabular}


Wetland F occurs within the southwestern portion of the borrow area (Figure 2). It appears on the NWI map as "palustrine, unconsolidated bottom, intermittently exposed, diked/impounded." This wetland encompasses a small pond, about 0.24 ha (0.6 acre) in size, and receives surface runoff from the surrounding upland areas, which are grassy and shrubby old-fields (Figure 8). The pond was created by placement of an earthen embankment across an intermittent stream. The embankment is overgrown with trees and shrubs, including Ulmus americana and Gleditsia triacanthos; the shallow water areas around the edge of the pond support emergent vegetation such as Eleocharis obtusa and Leersia oryzoides (Table 8). The wetland drains to the southwest into headwaters of wetland $K$ (Figure 2) via seepage through and around the embankment (wetland $\mathrm{K}$ is not located within the borrow area and haul road corridor). Soils at wetland F are hydric, based on a low chroma matrix color (10YR4/2, mottled) (Environmental Laboratory 1987). The total area of wetland $F$ is approximately 0.05 ha (0.12 acre).

Wetland $\mathrm{G}$ is located in the southwest corner of the borrow area (Figure 2). It is a small naturally occurring wetland, about 0.03 ha ( 0.07 acre) in size, situated in a depression that receives surface runoff from the surrounding upland area (Figure 9). The entire wetland is covered by a canopy of mature Acer saccharinum; emergent vegetation includes Scirpus atrovirens and Polygonum punctatum (Table 9). This wetland is inundated for much of the growing season. Soils at wetland G are hydric, based on a low chroma matrix color (10YR4/1, mottled) (Environmental Laboratory 1987).

Wetland $H$, about 0.04 ha ( 0.09 acre) in size, is located in the southwest corner of the borrow area, about $50 \mathrm{~m}$ ( $165 \mathrm{ft}$ ) south of wetland G (Figure 2). It is situated within a shallow pond that receives surface runoff from the surrounding upland area (Figure 10). Mature trees line the perimeter of this wetland and include Acer saccharinum and Ulmus americana. Emergent vegetation includes Bidens frondosa, Leersia oryzoides, and Toxicodendron radicans (Table 10). This wetland is inundated throughout the growing season. Soils at wetland $\mathrm{H}$ are hydric, based on an aquic moisture regime (Environmental Laboratory 1987).

Wetlands $I, J, K$, and $L$ are not within the project area but receive drainage from it (Figure 2). Wetland $I$ is Lake 36 in the Busch Conservation Area. Lake 36 is a perennial pond and appears on the NWI map as "palustrine, unconsolidated bottom, intermittently exposed, diked/impounded." It receives drainage, via an intermittent stream, from wetland A and the haul road corridor, approximately $0.38 \mathrm{~km}(0.24 \mathrm{mi})$ distant.

Wetland J, known as Frog Pond, is located on the Weldon Spring site, approximately $7.0 \mathrm{~m}$ (23 ft) from the northeast DOE property fence adjoining the haul road corridor. This wetland appears on the NWI map as "palustrine, unconsolidated bottom, intermittently exposed, diked/impounded." It contains a small pond, about 0.2 ha ( 0.5 acre) in size. The pond was created by placement of an earthen embankment across an intermittent stream. It receives drainage from a nearby highway maintenance facility and the haul road corridor, as well as from surrounding upland areas. Wetland $J$ drains into wetland $A$ via seepage 


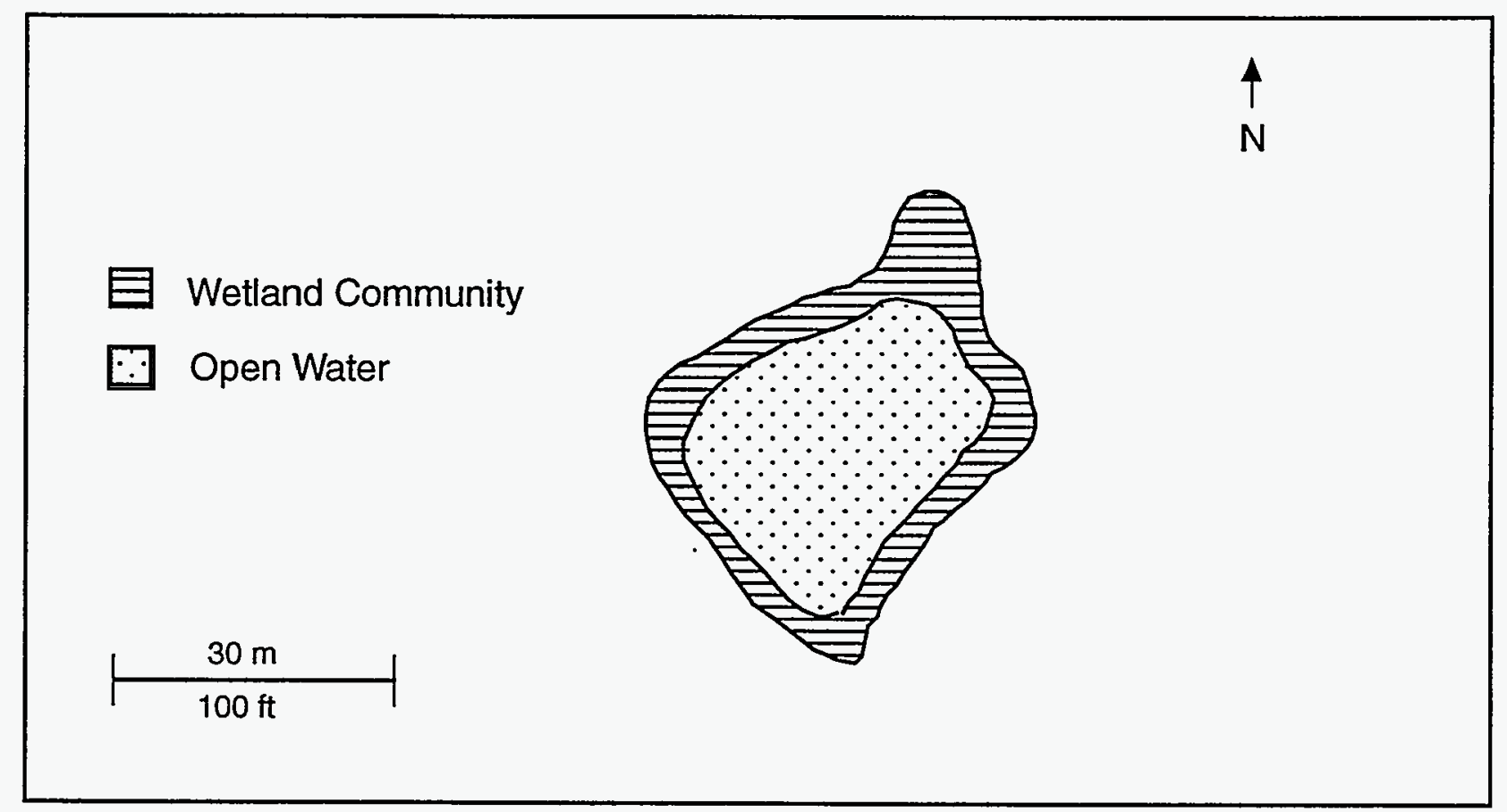

FIGURE 8 Diagram Showing Vegetational Community and Open Water of Wetland F

TABLE 8 Dominant Plant Species and Indicator Status of Wetland $F$

\begin{tabular}{lc}
\hline \multicolumn{1}{c}{ Dominant Species } & $\begin{array}{c}\text { Wetland } \\
\text { Indicator Status }\end{array}$ \\
\hline Agalinis tenuifolia & FACW \\
Bidens polylepis & FACW \\
Boehmeria cylindrica & OBL \\
Echinochloa muricata & OBL \\
Eleocharis obtusa & OBL \\
Leersia oryzoides & OBL \\
Lemna minor & OBL \\
Salix nigra & OBL \\
Toxicodendron radicans & FAC + \\
\hline
\end{tabular}




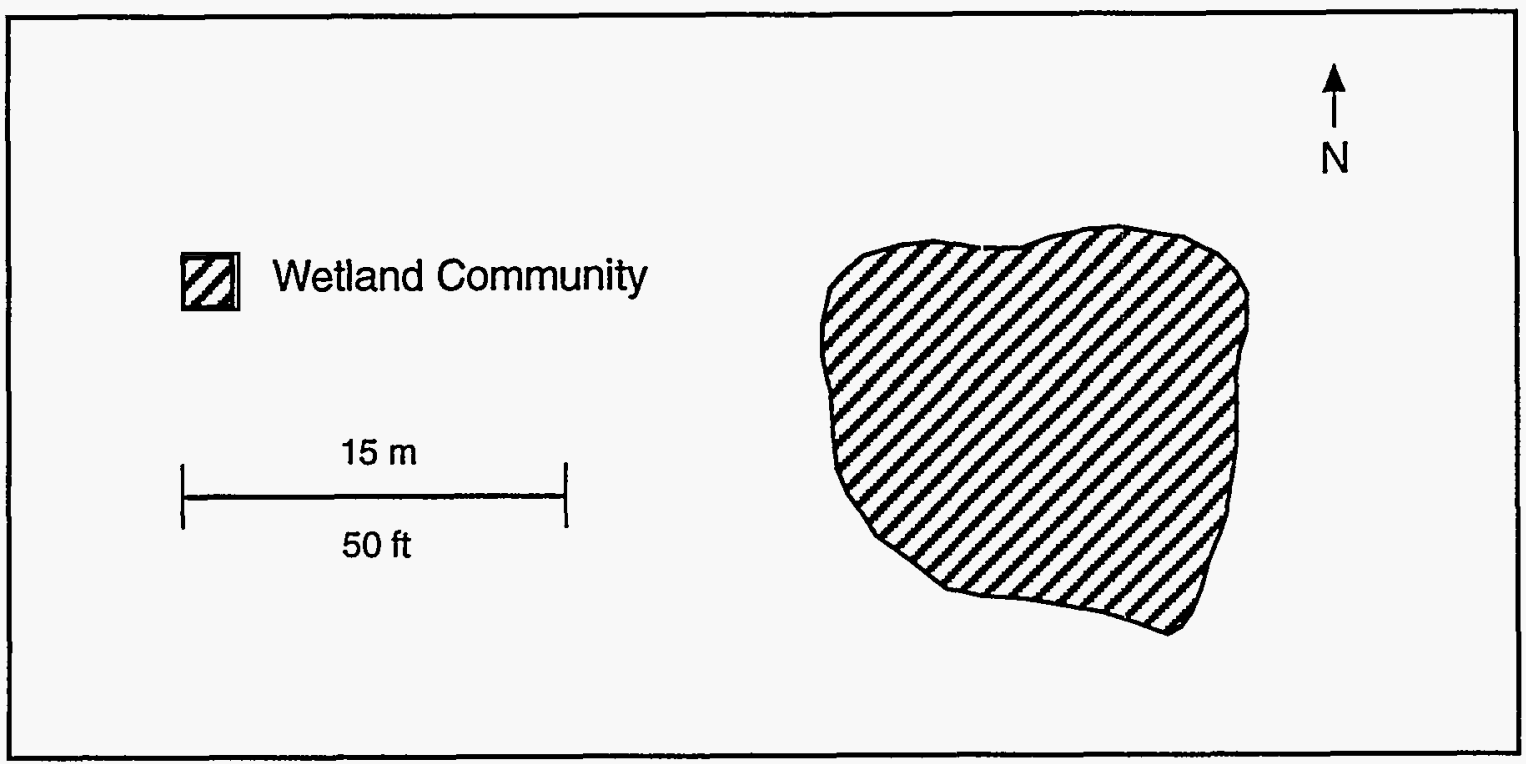

FIGURE 9 Diagram of Wetland G

TABLE 9 Dominant Plant Species and Indicator Status of Wetland G

\begin{tabular}{lc}
\hline \multicolumn{1}{c}{ Dominant Species } & $\begin{array}{c}\text { Wetland } \\
\text { Indicator Status }\end{array}$ \\
\hline Acer saccharinum & FACW \\
Polygonum punctatum & OBL \\
Scirpus atrovirens & OBL \\
Toxicodendron radicans & FAC + \\
\hline
\end{tabular}




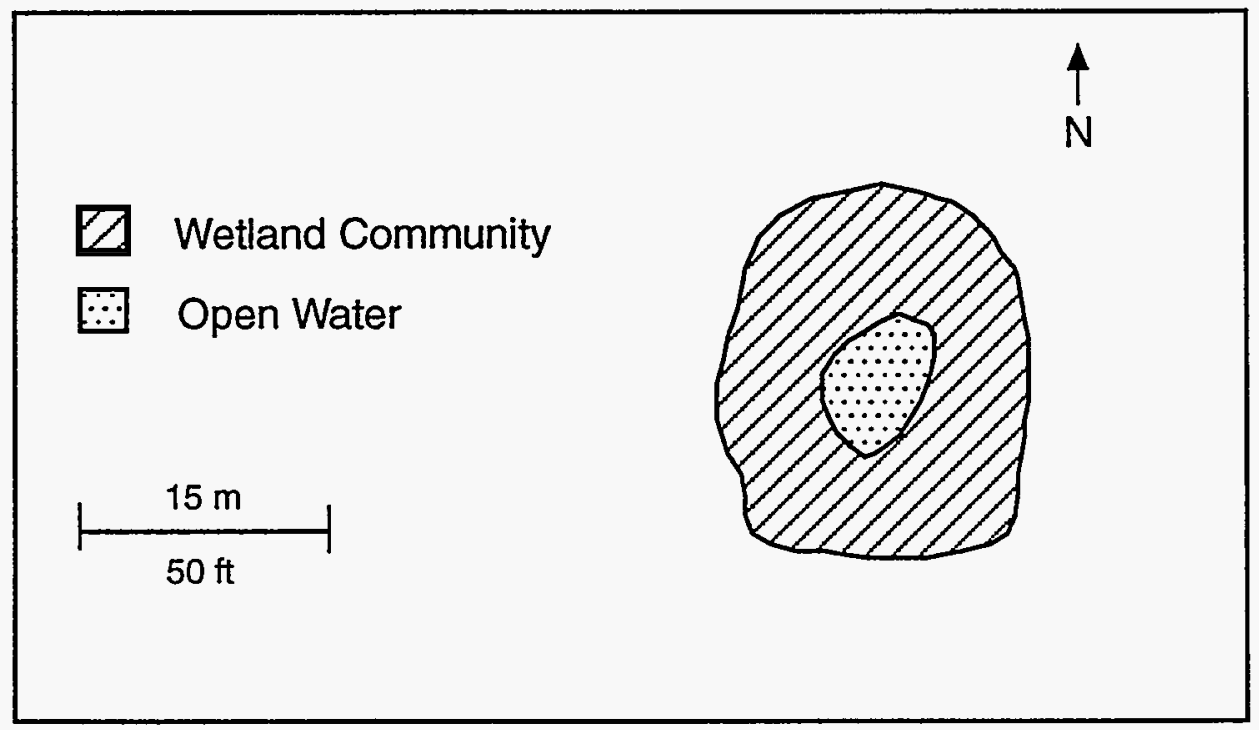

FIGURE 10 Diagram Showing Vegetational Community and Open Water of Wetland $H$

TABLE 10 Dominant Plant Species and Indicator Status of Wetland $H$

\begin{tabular}{ll}
\hline \multicolumn{1}{c}{ Dominant Species } & $\begin{array}{c}\text { Wetland } \\
\text { Indicator Status }\end{array}$ \\
\hline Acer saccharinum & FACW \\
Bidens frondosa & FACW \\
Eleocharis obtusa & OBL \\
Polygonum punctatum & OBL \\
Toxicodendron radicans & FAC+ \\
Ulmus americana & FACW- \\
\hline
\end{tabular}


through the embankment. Uplands surrounding this wetland are mostly deciduous forest, with mowed grass and a gravel covered storage area to the southwest. The shallow water areas around the perimeter of the pond support emergent vegetation.

Wetland $\mathrm{K}$ is a tributary of the Missouri River. The upper portion is an intermittent stream appearing on the NWI map as "intermittent riverine, stream bed, seasonally flooded." Farther downstream, it is listed as "lower perennial riverine, unconsolidated bottom, intermittently exposed." This stream receives drainage from the haul road corridor and the borrow area, including wetland $F$.

Wetland L contains Prairie Lake (about 14 ha [35 acres] in area), located about $0.64 \mathrm{~km}(0.4 \mathrm{mi})$ northeast of the borrow area. It appears on the NWI map as "lacustrine, limnetic, unconsolidated bottom, permanently flooded, diked/impounded." This wetland receives drainage from the borrow area, and wetland $D$ in particular, via an intermittent stream. The borrow area contains a fairly large portion of the Prairie Lake watershed.

\subsubsection{Potential Impacts}

Development of the borrow area and haul road corridor would entirely eliminate five wetlands and portions of one other, and would impact two wetlands incidentally. Without proper mitigative measures, four wetlands located outside the project area also could be impacted. The potential impacts to these wetlands are as follows:

- Approximately $0.04 \mathrm{ha}(0.09$ acre) of wetland A would be eliminated by construction of the haul road. Portions of this wetland outside the project area (particularly downstream) would be susceptible to sedimentation during construction and operation of the haul road.

- Wetland B, 0.04 ha (0.09 acre), is located within the haul road corridor and might be eliminated or be susceptible to sedimentation as a result of construction activities or haul road traffic.

- Wetland C, 0.13 ha (0.33 acre), is located within the borrow area and would be eliminated during excavation.

- Wetland D, 0.47 ha (1.17 acres), is located within the borrow area and would be eliminated during excavation.

- Wetland E, 0.08 ha (0.21 acre), is located within the borrow area and would be eliminated during excavation.

- Wetland F, 0.05 ha (0.12 acre), is located within the borrow area and could be eliminated during excavation; however, it would probably become inundated within a sedimentation pond. Continuous inundation would eliminate existing wetland vegetation by drowning and burial under accumulated sediment. 
- Wetland G, 0.03 ha ( 0.07 acre), is located within the borrow area and would be impacted during vegetation-clearing activities. Although this wetland is not located in an area designated for excavation, its proximity to the borrow area perimeter fence, service road, and stockpile area would make it highly susceptible to disturbance.

- Wetland H, 0.04 ha (0.09 acre), is located within the borrow area and would be impacted during vegetation-clearing activities. Although this wetland is not located in an area designated for excavation, its proximity to the borrow area perimeter fence and service road would make it highly susceptible to disturbance.

- Wetland I, although not located within the borrow area and haul road corridor, receives drainage from the haul road corridor and might be susceptible to sedimentation impacts as a result of construction activities.

- Wetland J, although not located within the borrow area and haul road corridor, receives drainage from the haul road corridor and might be susceptible to sedimentation impacts as a result of construction activities. Wetland $J$ is designated in the RI/FS-EIS for cleanup and would thus be subjected to removal of vegetation and soil.

- Wetland $\mathrm{K}$, although not located within the borrow area and haul road corridor, might be susceptible to sedimentation as a result of construction and operation activities in the haul road corridor and borrow area. Uncontrolled runoff from these areas might introduce toxic materials (such as fuels, oils, and coolants) into this wetland.

- Wetland L, although not located within the borrow area and haul road corridor, receives drainage from most of the northeastern portion of the borrow area and might be susceptible to sedimentation or contamination (e.g., from fuels) as a result of construction activities. Hydrological input from the borrow area would be maintained during and after borrow operations by surface regrading of the excavated area. Thus, this wetland should not experience reduced water levels as a result of borrow area development.

In summary, approximately 0.9 ha ( 2.2 acres) of wetland could be eliminated by borrow excavation and associated activities. A Section 404 permit authorization, under Nationwide General Permit 26, has been obtained from the Corps of Engineers. The wildlife habitat provided by the wetlands would also be eliminated and would not be replaced at the borrow area. At the conclusion of borrow activities, the borrow area and haul road corridor would be regraded to maintain original drainage patterns and would be seeded with native grasses. 


\section{WETLAND/SHOREBIRD COMPLEX}

To mitigate wetland loss at the borrow area and chemical plant area, DOE is providing funding to the Missouri Department of Conservation for development of a wetland/ shorebird complex within the Busch Conservation Area (MK-Ferguson Company and Jacobs Engineering Group 1994). The proposed 23-ha (57-acre) complex would be located in the northeastern portion of the conservation area, along Dardenne Creek (Figure 11). An earthen dike approximately $1,460 \mathrm{~m}(4,800 \mathrm{ft})$ long with a maximum height of $1.8 \mathrm{~m}(6.0 \mathrm{ft})$, would be constructed to impound surface water runoff from the drainage area. A water-level control structure would be built into the levee to allow for active management of water levels within the complex. The Missouri Department of Conservation would manage water levels on a seasonal basis to provide habitat for resident and migratory waterfowl and shorebirds, as well as suitable habitat for other biota.

Within this wetland/shorebird complex, DOE would promote the development of approximately 2 ha (5 acres) of replacement wetlands to mitigate for the wetlands that would be eliminated at the borrow area and haul road corridor. The remainder of the complex represents mitigation for the contaminated wetland habitats that will be eliminated as a result of remedial action at the chemical plant area.

Because a portion of the proposed wetland/shorebird complex would be located within the 100-year floodplain of Dardenne Creek, and a small amount of existing wetlands would be impacted by the complex, floodplain and wetland surveys were performed for this area. The results of these surveys are presented in Sections 3.1 and 3.2.

\subsection{FLOODPLAINS}

The Flood Insurance Rate Map for St. Charles County (Federal Emergency Management Agency 1992a) was used to delineate the 100-year floodplain at the location of the proposed wetland/shorebird complex and adjacent reaches of Dardenne Creek.

\subsubsection{Description}

Portions of the proposed wetland/shorebird complex are located within the 100-year floodplain of Dardenne Creek just upstream of U.S. Highway 40/61 (Federal Emergency Management Agency 1992a). The wetland/shorebird complex would encroach the 100-year floodplain of Dardenne Creek, including a portion of the floodway, for a length of about $914 \mathrm{~m}$ $(3,000 \mathrm{ft})$. A plan view of the wetland/shorebird complex and its relationship to the floodway of the 100-year flood is shown in Figure 11. Figure 12 shows an approximate cross section of Dardenne Creek and its 100-year floodplain (based on the Weldon Spring quadrangle map with a contour interval of $10 \mathrm{ft}$ ) at the mid-length of the wetland (U.S. Geological Survey 1982). 


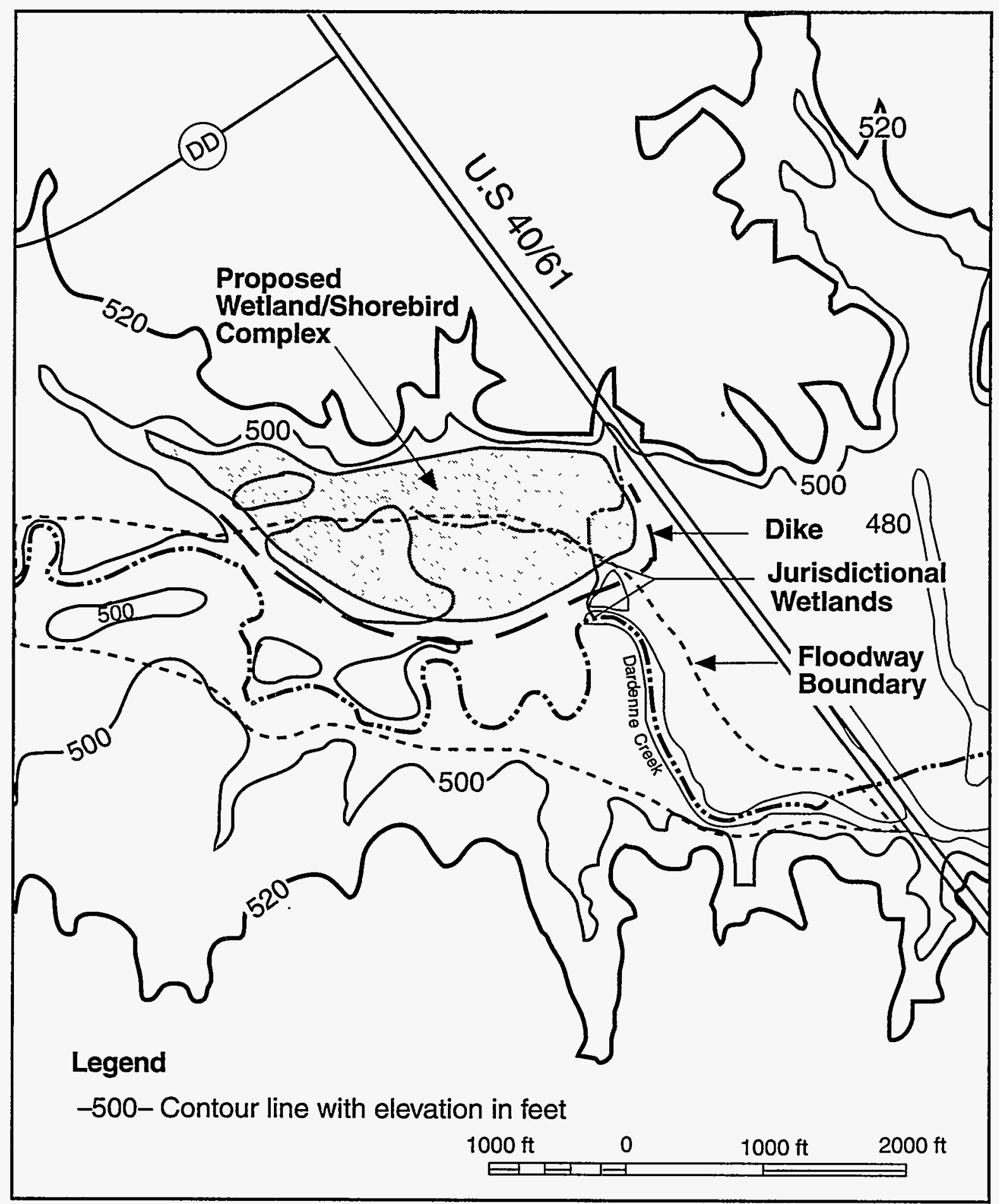

FIGURE 11 Proposed Wetland/Shorebird Complex within the Busch Conservation Area 
Cross Section of Dardenne Creek (Looking Downstream)

at 4,700 ft Upstream of the Centerline of U.S. Route 40/61

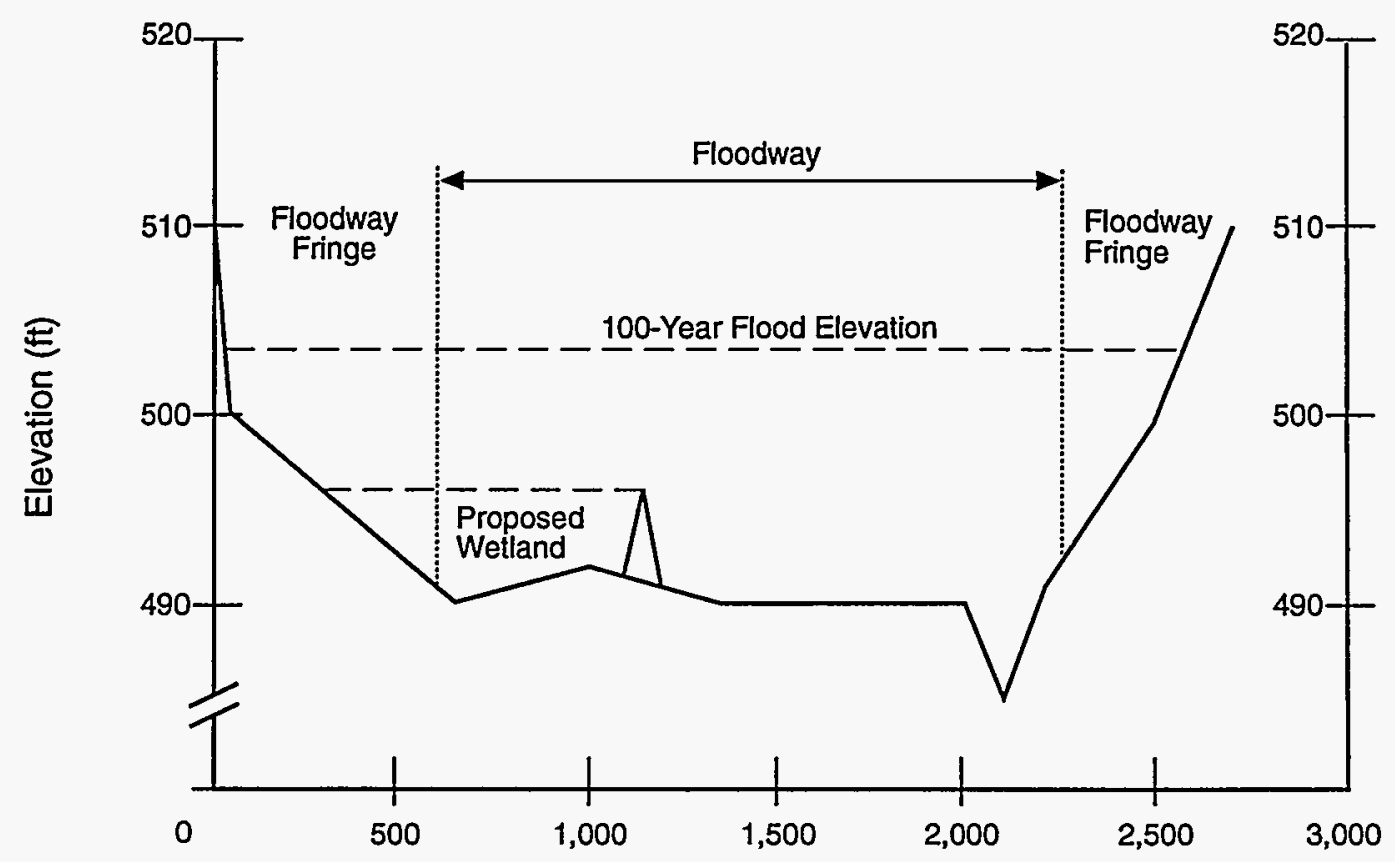

Distance (ft)

FIGURE 12 Cross Section of Dardenne Creek Showing the Floodway and Floodway Fringe

\subsubsection{Potential Impacts}

Encroachment on floodplains - such as the earthen dike that must be constructed to create the wetland/shorebird complex - reduces flood-carrying capacity, increases the flood heights of the streams, and increases flood hazards in areas upstream of the encroachment. Under the National Flood Insurance Program (Federal Emergency Management Agency 1992b), floodplains are managed under a concept in which the area of the 100-year flood is divided into a floodway and a floodway fringe (Figure 12). The floodway is the channel of a stream plus any adjacent floodplain areas that must be kept free of encroachment so that the 100-year flood may be carried without substantial increases in flood heights; minimum standards of the Flood Insurance Program limit such height increases to $0.3 \mathrm{~m}$ (1.0 ft). The area between the floodway and the boundary of the 100-year floodplain is called the floodway fringe. This fringe can be completely obstructed without substantial increase in the 100-year flood height, as defined by the Flood Insurance Program, at any point upstream of the obstruction.

The cross section shown in Figure 12 shows the approximate maximum extent of encroachment of the floodway by the wetland/shorebird complex dike. Because the 
cross-sectional area encroached by the dike and associated wetlands appears to be about the same as the floodway fringe area below the 100-year flood height, the flood height increase due to the proposed dike would probably be within that allowed by the Flood Insurance Program if no other encroachment of the floodplain occurred. The flood height increase would gradually become smaller in the area upstream of the obstruction. The stream reach downstream of the obstruction would not be affected.

\subsection{WETLANDS}

The NWI maps (FWS 1989) and site visits by wetland specialists from Argonne National Laboratory were used to identify the occurrence of wetlands at the location of the proposed wetland/shorebird complex. All wetlands were delineated within this area on the basis of the 1987 Corps of Engineers Wetlands Delineation Manual (Environmental Laboratory 1987).

\subsubsection{Description}

The proposed wetland/shorebird complex is located within the Busch Conservation Area, approximately $5.3 \mathrm{~km}$ (3.3 mi) northwest of the borrow area, in the Dardenne Creek drainage (Figure 11). A number of intermittent streams flow through the 23-ha (57-acre) project area. A woody riparian zone borders these streams and ranges from a narrow band approximately $7.6 \mathrm{~m}$ ( $25 \mathrm{ft}$ ) wide to a lowland forest up to $76 \mathrm{~m}$ (250 ft) wide. Much of this riparian zone and lowland forest appears on the NWI map (FWS 1989), as shown in Figure 13. Approximately 4.0 ha (10 acres) are classified as "palustrine, forested, broad-leaved deciduous, temporarily flooded" wetlands. Palustrine wetlands are small nontidal wetlands in shallow still water or variably flooded areas; temporarily flooded wetlands are wetlands in which surface water occurs briefly during the growing season while the water table usually lies well below the surface (Cowardin et al. 1979). Common plant species occurring within this wetland acreage are Acer saccharinum, Acer negundo, Celtis occidentalis, Quercus macrocarpa, Toxicodendron radicans, and Parthenocissus quinquefolia.

Wetland delineations were conducted at the proposed location of the wetland/ shorebird complex in September 1993. Areas that met the three criteria for jurisdictional wetland (hydrophytic vegetation, wetland hydrology, and hydric soils) are located along the banks of the principal stream, which is a tributary of Dardenne Creek (Figure 11). The streambank in this area is steep and ranges from about $0.9 \mathrm{~m}(3 \mathrm{ft}$ ) to about $4.6 \mathrm{~m}(15 \mathrm{ft}$ ) high. The wetland area is approximately $0.9 \mathrm{~m}(3 \mathrm{ft})$ wide along the lower portion of the bank and extends approximately $183 \mathrm{~m}$ (600 ft) upstream of the confluence with Dardenne Creek. Thus, about 0.03 ha ( 0.08 acre) of jurisdictional wetland was identified within the project area. The plant species of the wetland area are herbaceous and include Leersia virginica, Pilea pumila, Polygonum punctatum, Ludwigia palustris, and Acalypha rhomboidea (Table 11). The soil is Dockery silt loam, a hydric soil, and is frequently flooded. 


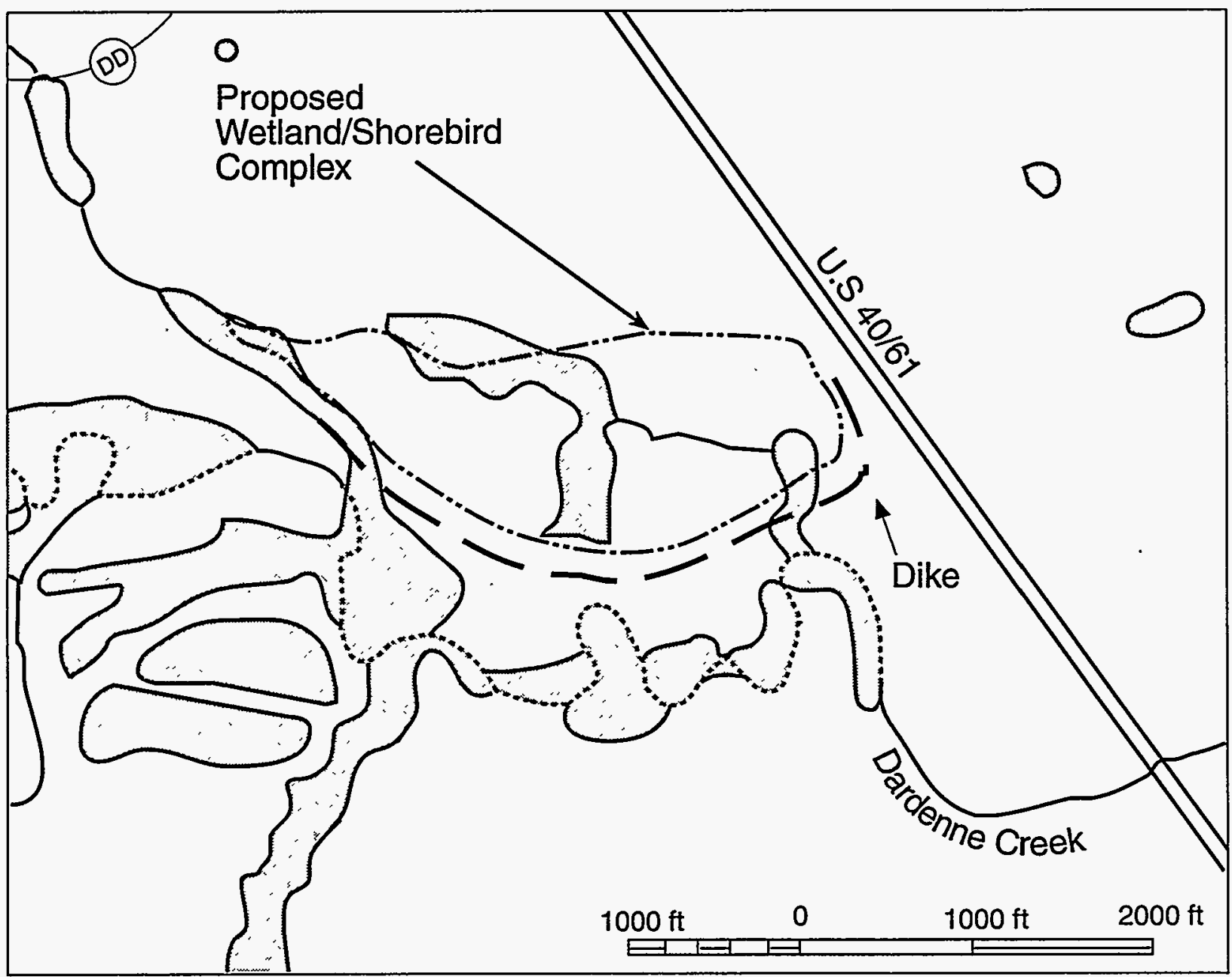

FIGURE 13 NWI Wetlands in the Vicinity of the Proposed Wetland/Shorebird Complex

TABLE 11 Dominant Wetland Plant Species of the Wetland/Shorebird Complex

\begin{tabular}{lll}
\hline \multicolumn{1}{c}{ Scientific Name } & Common Name & $\begin{array}{c}\text { Wetland } \\
\text { Indicator Status }\end{array}$ \\
\hline Acalypha rhomboidea & Common copper-leaf & FACU \\
Leersia virginica & Whitegrass & FACW \\
Ludwigia palustris & Marsh seedbox & OBL \\
Pilea pumila & Canada clearweed & FACW \\
Polygonum punctatum & Dotted smartweed & OBL \\
\hline
\end{tabular}

a Nomenclature follows Reed (1988). 


\subsubsection{Potential Impacts}

Construction of the earthen dike would eliminate about 0.03 ha $(0.08$ acre $)$ of jurisdictional wetlands in the area. A Section 404 permit authorization, under Nationwide General Permit 26, has been obtained by the Missouri Department of Conservation from the Corps of Engineers. The loss of these wetlands would represent only a short-term adverse impact to area wetlands. Following completion of the dike and initiation of watermanagement activities by the Missouri Department of Conservation, at least 0.03 ha $(0.08$ acre $)$ of new wetlands similar to the wetlands that were eliminated would be expected to develop.

Short-term impacts to adjacent wetlands located immediately downstream of the proposed wetland/shorebird complex could result from increased erosion and sedimentation during construction activities. The use of proper erosion-control procedures would ensure that these impacts would be minor, and such impacts would cease following completion of construction activities and revegetation of all disturbed areas. 


\section{MITIGATION}

\subsection{FLOODPLAINS}

The partial encroachment of the floodway at the wetland/shorebird complex would increase the 100-year flood elevation in the vicinity. The increase would probably be less than $0.3 \mathrm{~m}$ ( $1 \mathrm{ft}$ ), as allowed by the Flood Insurance Program. To prevent any greater increase, no other encroachment of either the floodway or floodway fringe in the vicinity should be allowed. Potential short-term impacts, resulting primarily from vegetation clearing and dike construction, should be mitigated by using good engineering practices and implementing the following measures:

- Erosion- and sediment-control measures - such as berms, silt fences, and covering exposed areas with mulch — should be used during all construction and contouring activities.

- Only clean fill should be used to construct the dike.

- Any excavated areas should be filled as soon as practicable after excavation and graded as appropriate.

- Disturbed areas should be revegetated as soon as possible following completion of all construction and grading activities.

\subsection{WETLANDS}

Potential adverse impacts to wetlands outside the borrow area and haul road corridor resulting from sedimentation would be partially mitigated by the use of good engineering practices to reduce or prevent erosion and sedimentation from disturbed areas. These practices might include using straw bales and siltation fences at drainage locations, covering exposed soil stockpiles, and seeding and mulching disturbed areas immediately following removal of borrow material. In addition, to collect surface runoff from disturbed areas, six sedimentation ponds would be constructed within the periphery of the borrow area at major drainage locations. Emergency spill plans would be developed to address accidental spills of fuels, solvents, and lubricants.

The elimination of wetlands within the borrow area and haul road corridor would be mitigated by the creation of 2 ha ( 5 acres) of replacement wetlands within the 23-ha (57-ha) wetland/shorebird complex to be developed by the Missouri Department of Conservation. The wetlands eliminated at the borrow area and haul road corridor would be replaced with wetlands containing similar plant species and providing similar wildlife habitat.

A monitoring program would be implemented to evaluate the success of the 2 ha (5 acres) of replacement wetlands. The monitoring program would include surveys of wetland vegetation and use of the area by waterfowl and other biota, and would continue for a period of three years following completion of the dike. 


\section{ALTERNATIVES}

Three alternative locations for the borrow area were previously identified but eliminated as suitable locations for borrow material. Alternative borrow area 1 was located about $2 \mathrm{~km}(1.2 \mathrm{mi})$ southwest of the chemical plant area in the Weldon Spring Conservation Area. Geotechnical testing at this location revealed the soils to be unsuitable for disposal cell construction and other needs related to remedial action at the chemical plant area (MK-Ferguson Company and Jacobs Engineering Group 1990).

Alternative borrow area 2 was located immediately west of the chemical plant area in the Army Reserve and National Guard Training Area. This location was eliminated from further consideration primarily because (1) desired soil types are widely scattered and of limited thickness and (2) the soil is potentially contaminated from past Army activities (Morrison Knudsen Corporation 1992). Alternative borrow area 3 was located north of the chemical plant area within the Busch Conservation Area. This location was eliminated as a borrow source because of (1) inappropriate geotechnical characteristics and (2) potential impacts to recreational activities and facilities in the conservation area and to traffic on State Route D (Morrison Knudsen Corporation 1992).

Avoidance of existing wetlands within the borrow area and haul road corridor is not a feasible alternative. The excavation depth at the borrow area would result in the wetlands being situated up to $6.7 \mathrm{~m}$ ( $22 \mathrm{ft}$ ) above the surrounding topography, resulting in drainage of surface runoff and subsurface water away from the wetlands. Also, rerouting the haul road corridor would impact a similar or greater amount of wetlands, as well as forested areas that would not be affected under the selected haul road location.

No alternatives were evaluated for the location of the wetland/shorebird complex. This area represents the location selected by the Missouri Department of Conservation for any DOE wetland mitigation activities undertaken to mitigate for impacts to existing wetlands within the Busch and Weldon Spring Conservation Areas. 


\section{REFERENCES}

Brabander, J.J., 1991, letter from J.J. Brabander (Field Supervisor, U.S. Fish and Wildlife Service, Columbia Field Office, Columbia, Mo.) to S.H. McCracken (Project Manager, Weldon Spring Site Remedial Action Office, Weldon Spring, Mo.), June 13.

Brabander, J.J., 1994, letter from J.J. Brabander (Field Supervisor, U.S. Fish and Wildlife Service, Columbia Field Office, Columbia, Mo.) to J.S. VanFossen (Deputy Project Manager, Weldon Spring Site Remedial Action Office, Weldon Spring, Mo.), March 7.

Cowardin, L.M., et al., 1979, Classification of Wetlands and Deepwater Habitats of the United States, FWS/OBS-79/31, U.S. Fish and Wildlife Service, Washington, D.C.

Crigler, D.J., 1993, letter from D.J. Crigler (Wildlife Management Biologist, August A. Busch Conservation Area, Missouri Department of Conservation, St. Charles, Mo.) to S.H. McCracken (Project Manager, Weldon Spring Site Remedial Action Project, Weldon Spring, Mo.) Sept. 16.

DOE: see U.S. Department of Energy.

Environmental Laboratory, 1987, Corps of Engineers Wetlands Delineation Manual, Technical Report Y-87-1, U.S. Army Engineer Waterways Experiment Station, Vicksburg, Miss.

Federal Emergency Management Agency, 1992a, Flood Insurance Rate Map, St. Charles County, Missouri and Incorporated Areas, panel 105 of 250, Dec. 15.

Federal Emergency Management Agency, 1992b, Flood Insurance Study, St. Charles County, Missouri and Incorporated Areas, Dec. 15.

Federal Insurance Administration, 1978a, Flood Insurance Rate Map, St. Charles County, Missouri (Unincorporated Areas), community-panel number 2903150250 A, page 250 of 350, U.S. Department of Housing and Urban Development, National Flood Insurance Program.

Federal Insurance Administration, 1978b, Flood Insurance Rate Map, St. Charles County, Missouri (Unincorporated Areas), community-panel number 2903150325 A, page 325 of 350, U.S. Department of Housing and Urban Development, National Flood Insurance Program.

Federal Insurance Administration, 1978c, Flood Insurance Rate Map, St. Charles County, Missouri (Unincorporated Areas), community-panel number 2903150100 A, page 100 of 350, U.S. Department of Housing and Urban Development, National Flood Insurance Program.

FWS: see U.S. Fish and Wildlife Service. 
Hlohowskyj, I., 1990, letter from I. Hlohowskyj (Environmental Assessment and Information Sciences Division, Argonne National Laboratory, Argonne, Ill.) to J. Scott (Department of the Army, Kansas City District, Corps of Engineers, Kansas City, Mo.), Nov. 5.

Jewett, M.D., 1990, letter from M.D. Jewett (Chief, Regulatory Branch, Operations Division, Department of the Army, Kansas City District, Corps of Engineers) to I. Hlohowskyj (Environmental Assessment and Information Sciences Division, Argonne National Laboratory, Argonne, Ill.), Dec. 6.

Jewett, M.D., 1994, letter from M.D. Jewett (Chief, Regulatory Branch, Operations Division, Department of the Army, Kansas City District, Corps of Engineers) to J.R. Powers (MK-Ferguson Company, St. Charles, Mo.), March 11.

McCracken, S.H., 1991a, letter from S.H. McCracken (Project Manager, Weldon Spring Site Remedial Action Project, Weldon Spring, Mo.) to J. Brabander (Columbia Field Office, U.S. Fish and Wildlife Service, Columbia, Mo), May 15.

McCracken, S.H., 1991b, letter from S.H. McCracken (Project Manager, Weldon Spring Site Remedial Action Project, Weldon Spring, Mo.) to J. Brabander (Columbia Field Office, U.S. Fish and Wildlife Service, Columbia, Mo), Aug. 7.

Missouri Department of Conservation, 1989, Area Management Plan for the August A. Busch Complex, Jefferson City, Mo.

MK-Ferguson Company and Jacobs Engineering Group, 1990, WSSRAP Chemical Plant Geotechnical Investigations, DOE/OR/21548-158, prepared for U.S. Department of Energy, Oak Ridge Operations Office, Weldon Spring Site Remedial Action Project, St. Charles, Mo., Dec.

MK-Ferguson Company and Jacobs Engineering Group, 1994, WSSRAP Wetlands Project Plan for COE Permit Application, DOE/OR/21548-437, Rev. A, prepared for U.S. Department of Energy, Oak Ridge Field Office, Weldon Spring Site Remedial Action Project, St. Charles, Mo., Jan.

Morrison Knudsen Corporation, 1992, WSSRAP - Disposal Facility, Low-Permeability Borrow Investigation - Supporting Study No. 5A: Evaluation of Potential Borrow Sources for Low-Permeability Soils, Technical Memorandum No. 3840TM-548-00, Rev. 0; MKES Doc. No. 3840D:SD-K-01-4648-0, prepared by Morrison Knudsen Corporation, Environmental Services Division, San Francisco, Calif., for MK-Ferguson Company, Weldon Spring Site Remedial Action Project, St. Charles, Mo., Jan. 10.

Reed, P.B., Jr., 1988, National List of Plant Species that Occur in Wetlands: North Central (Region 3), U.S. Fish and Wildlife Service Biological Report 88 (26.3). 
Reitinger, J.M., 1992, "Ecological Survey of the Proposed Soil Borrow Area," memorandum from J.M. Reitinger (MK-Ferguson Company, St. Charles, Missouri) to L. Gonzales and M. Gilbert (MK-Ferguson Company, St. Charles, Missouri), Oct. 28.

U.S. Department of Energy, 1992a, Baseline Assessment for the Chemical Plant Area of the Weldon Spring Site, DOE/OR/21548-091, prepared by U.S. Department of Energy, Oak Ridge Field Office, Weldon Spring Site Remedial Action Project, with technical assistance from Argonne National Laboratory, Environmental Assessment and Information Sciences Division, Nov.

U.S. Department of Energy, 1992b, Feasibility Study for Remedial Action at the Chemical Plant Area of the Weldon Spring Site, DOE/OR/21548-148, Vol. I, prepared by U.S. Department of Energy, Oak Ridge Field Office, Weldon Spring Site Remedial Action Project, with technical assistance from Argonne National Laboratory, Environmental Assessment and Information Sciences Division, Nov.

U.S. Department of Energy, 1992c, Proposed Plan for Remedial Action at the Chemical Plant Area of the Weldon Spring Site, DOE/OR/21548-160, prepared by U.S. Department of Energy, Oak Ridge Field Office, Weldon Spring Site Remedial Action Project, with technical assistance from Argonne National Laboratory, Environmental Assessment and Information Sciences Division, Nov.

U.S. Department of Energy, 1992d, Remedial Investigation for the Chemical Plant Area of the Weldon Spring Site, DOE/OR/21548-074, Rev. 0, Vols. I-II, prepared by MK-Ferguson Company and Jacobs Engineering Group, Weldon Spring, Mo., for U.S. Department of Energy, Oak Ridge Field Office, Weldon Spring Site Remedial Action Project, Weldon Spring, Mo., Nov.

U.S. Department of Energy, 1992e, Addendum to the Remedial Investigation for the Chemical Plant Area of the Weldon Spring Site, DOE/OR/21548-272, prepared by MK-Ferguson Company and Jacobs Engineering Group, Weldon Spring, Mo., for U.S. Department of Energy, Oak Ridge Field Office, Weldon Spring Site Remedial Action Project, Weldon Spring, Mo., Nov.

U.S. Department of Energy, 1993a, Responses to Comments on the Remedial Investigation / Feasibility Study-Environmental Impact Statement for Remedial Action at the Chemical Plant Area of the Weldon Spring Site (November 1992), DOE/OR/21548-387, prepared by MK-Ferguson Company and Jacobs Engineering Group, Weldon Spring, Mo., for U.S. Department of Energy, Oak Ridge Field Office, Weldon Spring Site Remedial Action Project, Weldon Spring, Mo., June.

U.S. Department of Energy, 1993b, Record of Decision for Remedial Action at the Chemical Plant Area of the Weldon Spring Site, DOE/OR/21548-376, prepared by U.S. Department of Energy, Oak Ridge Field Office, Weldon Spring Site Remedial Action Project, Weldon Spring, Mo., Sept. 
U.S. Environmental Protection Agency, 1987, National Priorities List for Uncontrolled Hazardous Waste Sites, Final Rule (40 CFR Part 300), Federal Register 52(140):27620-27642, July 22.

U.S. Environmental Protection Agency, 1989, National Priorities List for Uncontrolled Hazardous Waste Sites, Final Federal Facility Site Update; Final Rule (40 CFR Part 300), Federal Register 54(47):10512-10517, March 13.

U.S. Environmental Protection Agency, 1990, National Priorities List for Uncontrolled Hazardous Waste Sites; Final Rule (40 CFR Part 300), Federal Register 55(35):6154-6176, Feb. 21.

U.S. Fish and Wildlife Service, 1989, National Wetlands Inventory Map, Weldon Spring Quadrangle, U.S. Department of the Interior, Fish and Wildlife Service, National Wetlands Inventory, St. Petersburg, Fla.

U.S. Geological Survey, 1982, Weldon Spring Quadrangle, 7.5 minute topographic map, U.S. Department of the Interior, Reston, Va. 